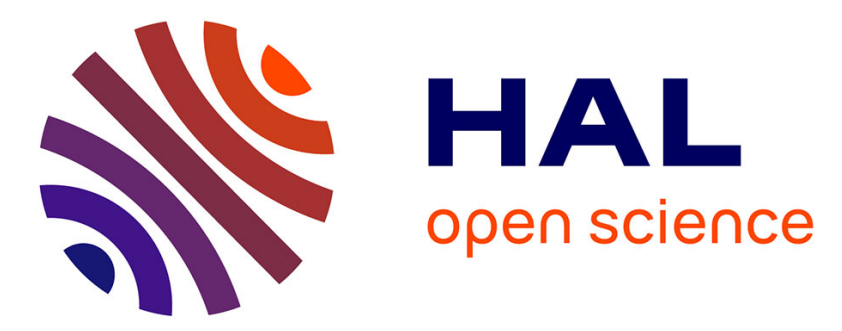

\title{
Influence of the Mediterranean Sea on the West African Monsoon: intraseasonal variability in numerical simulations
}

\author{
Marco Gaetani, Bernard Fontaine, Pascal Roucou, Marina Baldi
}

\section{- To cite this version:}

Marco Gaetani, Bernard Fontaine, Pascal Roucou, Marina Baldi. Influence of the Mediterranean Sea on the West African Monsoon: intraseasonal variability in numerical simulations. Journal of Geophysical Research: Atmospheres, 2010, pp.D24115. 10.1029/2010JD014436 . hal-00552946

\section{HAL Id: hal-00552946 https://hal.science/hal-00552946}

Submitted on 13 Jan 2011

HAL is a multi-disciplinary open access archive for the deposit and dissemination of scientific research documents, whether they are published or not. The documents may come from teaching and research institutions in France or abroad, or from public or private research centers.
L'archive ouverte pluridisciplinaire HAL, est destinée au dépôt et à la diffusion de documents scientifiques de niveau recherche, publiés ou non, émanant des établissements d'enseignement et de recherche français ou étrangers, des laboratoires publics ou privés. 
Influence of the Mediterranean Sea on the West African Monsoon: intraseasonal variability in numerical simulations

Marco Gaetani (corresponding author)

Istituto di Biometeorologia, IBIMET-CNR

Via dei Taurini 19, 00185 Rome, Italy

m.gaetani@ibimet.cnr.it

phone: +39(0)649937672; fax: +39(0)649937685

Bernard Fontaine

Centre de Recherches de Climatologie, CNRS/Université de Bourgogne,

6 Boulevard Gabriel, 21000 Dijon, France

bernard.fontaine@u-bourgogne.fr

\section{Pascal Roucou}

Centre de Recherches de Climatologie, CNRS/Université de Bourgogne,

6 Boulevard Gabriel, 21000 Dijon, France

pascal.roucou@u-bourgogne.fr

Marina Baldi

Istituto di Biometeorologia, IBIMET-CNR

Via dei Taurini 19, 00185 Rome, Italy

m.baldi@ibimet.cnr.it 


\begin{abstract}
The influence of May to September SST anomalies in the Mediterranean sea on the West African monsoon is investigated, analysing the outputs of numerical sensitivity experiments performed using three atmospheric general circulation models (ARPEGE, ECHAM, UCLA) in the framework of the AMMA-FP6 project. The precipitation and atmospheric dynamics response to the SST forcing is explored, in terms of intraseasonal variability, evaluating the results from the individual models and from the multi-model mean. A positive precipitation response to warmer than average conditions in the Mediterranean sea is found in the Sudano-Sahelian belt in August-September. The proposed dynamical mechanism underlying the Mediterranean action on the West African monsoon is based on the modifications produced by the SST forcing in the moisture content in the lower troposphere. A warmer eastern Mediterranean in August-September feeds the lower troposphere with additional moisture, with a consequent reinforcement of northerly moisture transport toward the Sahel. Furthermore, warmer SST is linked to a strengthening of the Saharan heat-low and to an enhancement of the moist static energy meridional gradient over West Africa, favouring the northward displacement of the monsoonal front.
\end{abstract}




\section{Introduction}

The understanding and predictability of the West African monsoon (WAM) activity are fundamental for the Sudano-Sahelian countries, whose economy, mainly based on rainfed agriculture, is vulnerable to climate variability. The analysis of rainfall variability at interannual and decadal timescales is therefore the basis for any short/long-term agricultural planning, while the correct description of the WAM seasonal cycle and of the mechanisms ruling the intraseasonal variability can be considered as the main factor to be taken into consideration for agricultural and food stocks management [Sultan et al., 2005].

The WAM activity spans over a wide range of time-scales, from intraseasonal [Sultan et al., 2003] to decadal [Lebel and Ali, 2009], and is sensitive to both local forcing and remote influences. In this respect, Giannini et al. [2003] emphasized the action of the ocean basins surrounding the African continent on the West Africa rainfall decadal trend, while Eltahir and Gong [1996] and, more recently, Joly and Voldoire [2009] pointed out the role of the Gulf of Guinea in the interannual modulation of the monsoonal circulation driven by the moist static energy content in the lower troposphere. Additionally, using numerical experiments, Losada et al. [2009] described the negative impact of the positive phase of the Atlantic Equatorial mode (the so called Atlantic Niño) on the WAM precipitation, while Raicich et al. [2003] found a positive correlation with the Indian monsoon, through a connection with the eastern Mediterranean basin. Furthermore, the relationship with the ENSO has been extensively explored and, in particular, periods of strong and weak correlation between WAM and ENSO have been identified by Janicot et al. [2001], who showed a significant negative impact of positive ENSO phases on the WAM precipitation after the 70s.

The role of the Mediterranean sea has been underestimated until the seminal work of Rowell [2003], who found a positive correlation between the Mediterranean SST and the WAM precipitation and 
explored the underlying dynamical mechanisms, finding a significant increase in the lower troposphere moisture content, advected toward the Sudano-Sahelian belt by the northeasterly flow crossing the Mediterranean. Also Fontaine et al. [2003] have shown that a sizeable moisture advection from the Mediterranean feeds the monsoonal front. More recently, empirical and numerical studies [Jung et al., 2006; Peyrillé et al., 2007; Peyrillé and Lafore, 2007] confirmed the connection between Mediterranean and WAM, a connection intensified in last years [Joly, 2008]. In the framework of the African Monsoon Multidisciplinary Analysis (AMMA-FP6 program; Redelsperger et al. [2006]) the WAM-Mediterranean connection has been investigated using atmospheric general circulation models (AGCMs). In this context, Fontaine et al. [2010] provided evidence that anomalous Mediterranean warm events are associated with a more intense monsoon, enhanced flux convergence and upward motion along the ITCZ, a strengthening of low level moisture advection, and a more northward location of ascending motion in West Africa. Furthermore, they found that in the western Mediterranean, surface temperature is statistically associated with the atmospheric deep convection over the Gulf of Guinea, while in the eastern Mediterranean the SST variability forces the atmospheric circulation over the North African subcontinent. Thus, anomalous eastern Mediterranean warm conditions are linked to a northward migration of the monsoon system accompanied by enhanced southwesterly flow and weakened northeasterly climatological wind.

While decadal and interannual WAM variability has been widely investigated, the intraseasonal variability has been for a long time less documented. The day-to-day rainfall variability has been first related to the African easterly waves regime [Diedhou et al., 1999; Gu et al., 2004] and to mesoscale convective systems [Mathon et al., 2002]. Then the northward installation of the WAM rainbelt has been analysed: it can be divided into four sub-periods, each composed of a pause and an active phase of precipitation, as described by Louvet et al. [2003]. Furthermore, Sultan et al. [2003] showed that precipitation and convection are mainly modulated by 10-25 day and 25-60 day 
periodicities. The mechanisms controlling this variability is still debated, although connections to the Madden-Julian oscillation [Lavender and Matthews, 2009] and to the intraseasonal variability of the Asian summer monsoon [Janicot et al., 2009] have been demonstrated.

The previous cited studies on the WAM-Mediterranean relationship focused on the interannual variability at a seasonal scale. In contrast, the sub-seasonal scale of the interaction has not been yet documented, although the variability internal to the WAM seasonal cycle is a crucial issue. The aim of this work is hence to explore the WAM-Mediterranean co-variability and connection at intraseasonal time-scale, by analysing the daily outputs from dedicated AGCMs sensitivity experiments prescribing warm and cold SST anomalies over the Mediterranean and performed in the framework of the AMMA-FP6 program for exploring the impact on WAM. This analysis will allow us to investigate (i) the major sub-seasonal features of the WAM in response to the Mediterranean SST forcing, i.e., the monsoon onset, and the African easterly waves activity; and also (ii) the timing of the response of major dynamical monsoonal features, i.e., the moisture transport and divergence, the moist static energy meridional gradient, and the Saharan heat-low and African easterly jet intensity and displacement.

In Section 2 the observational evidence of the WAM-Mediterranean connection is presented; in Section 3 the sensitivity experiments are described and the outputs are analysed, depicting the impact of the SST forcing on the monsoonal precipitation and the underlying dynamical mechanisms; in Section 4 the results are discussed and the conclusions are drawn.

\section{Observed Mediterranean/West African monsoon interannual relationship}

In this section the observed WAM-Mediterranean field relationship in the period 1979-2007 is first presented through a singular value decomposition (SVD) analysis [von Storch and Zwiers, 1999] of 
Mediterranean skin temperature and precipitation fields over West Africa at the interannual timescale. The SVD approach is used in order to identify covariance modes between surface conditions over the Mediterranean and the WAM activity. Then a few basic associated signals in atmospheric dynamics are analysed using composite analyses of wind and specific humidity to highlight the statistical relationship.

\subsection{Data}

We use the rainfall data from Climate Prediction Center Merged Analysis of Precipitation (CMAP; Xie and Arkin [1997]) and Global Precipitation Climatology Project (GPCP; Xie et al. [2003]), and the atmospheric variables from the NCEP-DOE AMIP-II Reanalysis (R-2; Kanamitsu et al. [2002]). The CMAP and GPCP data are obtained as a merging of raingauges observations and satellite estimations. Monthly and pentad values are available from 1979 to 2008, on a global domain at $2.5^{\circ}$ resolution starting from $\left(1.25^{\circ} \mathrm{E}, 88.75^{\circ} \mathrm{S}\right)$. The R-2 dataset is derived from the NCEP-NCAR Reanalysis, and it contains a wide range of atmospheric variables obtained as a merging of in situ and satellite observations and modeling. Monthly, daily and 6-hours values are available from 1979 to present, on a global domain at different resolutions (2.5 $5^{\circ}$ regular grid and T62 Gaussian grid) and vertical levels (pressure and “sigma” levels).

\subsection{SVD analysis}

The SVD analysis has been performed between skin temperature over the Mediterranean basin $\left[10^{\circ} \mathrm{W}-40^{\circ} \mathrm{E} ; 30^{\circ} \mathrm{N}-45^{\circ} \mathrm{N}\right]$ and WAM precipitation over the $0^{\circ}-15^{\circ} \mathrm{N}$ belt in May-June (MJ) and the $5^{\circ} \mathrm{N}-20^{\circ} \mathrm{N}$ belt in July-September (JAS). Different precipitation domains have been chosen in order to follow the meridional migration of the rainbelt embedded in the ITCZ, which is positioned along the coast of Guinea $\left(5^{\circ} \mathrm{N}\right)$ in $\mathrm{MJ}$, and abruptly shifts in late June to $10^{\circ} \mathrm{N}$ (preonset and onset 
phases; Sultan and Janicot [2003]). After the onset phase, in JAS, precipitation and convection persist over the Sudano-Sahelian belt [Gu and Adler, 2004]. In order to give the same weight to the different parameters describing the phenomenon and to focus on the interannual variability, we applied the SVD analysis to the standardized data after removing any linear trend at each grid-point in the domains.

In May-June, the first SVD mode (Fig. 1ab) explains only 33\% of the squared covariance fraction (SCF), although the correlation between the time series of the expansion coefficient (ECs) is high and significant $(r=0.65)$ : negative anomalies of surface temperature in the eastern Mediterranean are related to negative precipitation anomalies along the coast of Guinea and positive anomalies inland, but the pattern shows low significance. By contrast, in JAS, the pattern is largely significant: the first SVD mode (Fig. 1cd) explains 59\% of the SCF and the correlation between the ECs time series is $r=0.64$, indicating that warmer temperatures in the eastern Mediterranean are related to a wetter Sudan-Sahel. Thus, a significant statistical relationship exists between surface temperatures in the Mediterranean and precipitation over West Africa on an interannual time-scale: this relationship is active in JAS, when the monsoon is fully developed inland. However, part of the WAM-Mediterranean common variability can be ascribed to the Indian monsoon circulation that affects both the eastern Mediterranean basin [Raicich et al., 2006] and the north African summer circulation [Chen, 2005]. The modelling approach described in this work is helpful in determining and quantifying the direct action of the Mediterranean on the WAM variability.

\subsection{Atmospheric dynamics in July-September}

In order to investigate the atmospheric dynamics associated to the statistical WAM-Mediterranean relationship, we analyse the wind and humidity composite difference between the warm and cold situations in the Mediterranean, identified using the skin temperature ECs time series of the first 
SVD mode in JAS. The time series is divided in terciles, with the cold (warm) years in the first (third) tercile (Tab. 1) to amplify the skin temperature anomaly pattern in the first SVD mode, that explains the highest fraction of covariance.

In the lower troposphere, the JAS mean wind field (Fig. 2a) is characterized by a clear monsoonal southwesterly flow penetrating from the Gulf of Guinea inland into West Africa, while an anticyclonic (a cyclonic) circulation occurs over the western (eastern) Mediterranean. These inverse cells are associated with a northeasterly flow crossing the Sahara desert, limiting the inland penetration of the WAM but feeding the ITF convergence. In the upper troposphere, the circulation contrasts the extratropical westerlies and the easterlies in the Tropics (Fig. 2b). Composite results in Fig. 2c show that a warmer Mediterranean has an impact on the wind field in the lower troposphere, enhancing both the northeasterly flow from the eastern Mediterranean and the southwesterly flow from the Atlantic Ocean. This mechanism increases the flux convergence and the cyclonic circulation in the eastern part of North Africa, around $20^{\circ} \mathrm{N}$, while a significant southwesterly flow is observed at a latitude of $10^{\circ} \mathrm{N}$. In the upper troposphere, a weakening of the westerly flow along the Mediterranean coast of Africa and a strengthening along the Alps are observed (Fig. 2d). This is consistent with the correlation between the midlatitudes jetstream variability and the occurrence of anomalous summers in the Mediterranean [Baldi et al., 2006].

The JAS atmospheric moisture field is displayed at $850 \mathrm{hPa}$ because specific humidity is higher close to the surface (Fig. 3a). It shows a maximum in the Tropical belt and a minimum over the Sahara desert. Moisture is transported towards the monsoonal front both by the southwesterly flow from the Atlantic and across the desert from the Mediterranean (Fig. 3b). The warm-cold composite (Fig. 3c) displays significant positive humidity anomalies over the Mediterranean basin, due to enhanced evaporation from the warmer sea surface, and more southward along the monsoonal front. Thus, additional moisture is available for precipitation where northeasterlies and southwesterlies 
converge (Fig. 3d), while the enhanced southwesterly moisture transport from the Atlantic ocean is able to feed the rains on the western coast of North Africa (Fig. 3cd).

\section{Simulated Mediterranean/West African monsoon intraseasonal relationship}

The picture described in the previous section is fully consistent with other studies [Rowell, 2003; Raicich et al., 2003; Jung et al., 2006; Fontaine et al., 2010] showing that a warmer Mediterranean sea is favourable to the Sudan-Sahel precipitation. In this paragraph we discuss the potential impact of Mediterranean SST anomalies on the intraseasonal variability over the WAM region in MaySeptember, by analysing the daily outputs from the AMMA-FP6 numerical sensitivity experiments performed forcing the AGCMs with prescribed warm and cold SST anomalies over the Mediterranean sea.

\subsection{Sensitivity experiments and analysis methodology}

The numerical sensitivity experiments simulating normal conditions and warm/cold anomalies over the Mediterranean sea have been performed using three AGCMs:

- ARPEGE-CLIMAT [Déqué et al., 1994] Version 3, at T42 Gaussian resolution with 45 vertical levels, run at CNRM (National Center for Meteorological Research, France);

- ECHAM [Roeckner et al., 1996] Version 4, at T30 Gaussian resolution with 32 vertical levels, run at ENEA (National Agency for New Technologies, Energy and Sustainable Economical Development, Italy);

- UCLA model [Richter et al., 2008] Version 7.3, at $2.5^{\circ} \times 2^{\circ}$ lon-lat resolution and 29 vertical levels, run at UCM (Complutense University of Madrid, Spain).

The control experiments have been performed forcing the models with the 1979-2005 observed global SST climatology, while warm and cold experiments have been performed adding anomalous 
Mediterranean SST patterns to the observed SST climatology. The SST anomaly patterns have been constructed using the expansion coefficients of the leading extended maximum covariance mode between the WAM monthly precipitation (CMAP) and the Mediterranean monthly SST (NOAA Extended Reconstructed SST; Smith and Reynolds [2004]) on the period 1979-2005, as described in Polo et al. [2008]. This mode shows a strong positive relationship between the Sahelian precipitation and the spring to summer evolution of the eastern Mediterranean SST, therefore warm/cold SST composites were computed by averaging years for which the SST-precipitation coupling was maximal, i.e., choosing those years in which the SST and precipitation ECs are higher than 1 standard deviation $(1984,1987,1991,1992,1997)$ and those in which the expansion coefficients are less than -1 standard deviation (1979, 1994, 1999, 2001). The May to October monthly SST anomaly fields used to force the warm experiments are shown in Fig. 4. For each model and each experiment (control, warm, cold) we use 10 simulations, for a total of $10 \times 3 \times 3=$ 90 simulations from $15^{\text {th }}$ of April to $15^{\text {th }}$ of October, following the AMIP protocol [Gates, 1993], with initial conditions taken from years 1979 to 1988 . We have to specify that using a prescribed SST as a lower boundary condition implies that the sea acts as an infinite reservoir of heat capacity and this tends to damp the surface heat fluxes and therefore to decrease the amplitude of the results.

We analyse the outputs of each individual model and the multi-model mean (ensemble-mean). In order to limit the influence of models biases, for each model the control run is subtracted to the sensitivity experiment before to compute the warm/cold ensemble-mean anomalies. Because of differences in models horizontal resolution, the ensemble-mean is computed after linearly interpolating the individual models outputs over a $2.5^{\circ}$ resolution grid, with the starting point at $\left(0^{\circ} \mathrm{E}, 0^{\circ} \mathrm{N}\right)$. In order to describe the impact of the thermal anomalies in the Mediterranean sea on the WAM at a sub-seasonal time-scale, the differences between warm and cold simulations are computed and the results are displayed in time-latitude diagrams. The purpose of this approach is the determination of the timing of the relationship and the amplitude of the WAM modifications in 
terms of latitudinal position, exploiting the quasi-zonal displacement of the monsoonal front. The intraseasonal variability is investigated after filtering the daily outputs using a Butterworth low-pass filter [Murakami, 1979] with a 10 day cut-off, in order to remove the synoptic variability.

\subsection{WAM seasonal cycle in control experiments}

In order to evaluate the model capability to simulate the WAM seasonal cycle, we discuss the timelatitude diagrams of the May to September precipitation averaged between $10^{\circ} \mathrm{W}$ and $30^{\circ} \mathrm{E}$ (Fig. 5), for each model, for the ensemble-mean, and for the observations (CMAP and GPCP rainfall estimates). In addition, the seasonal evolution of the zonal wind at 850 and $600 \mathrm{hPa}$ in the models is compared to R-2, in order to verify the correct description of the main dynamical features associated with the WAM. The simulations outputs are compared with the 1979-1988 observations after filtering the daily model outputs and the R-2 data using a 10 day low-pass filter, while the CMAP and GPCP pentad data are filtered using a 2.5 pentad low-pass filter.

Observed rainfall data (Fig. 5ef) show clearly the installation of the WAM, following the seasonal meridional migration of the ITCZ, through a sequence of active phases and pauses [Louvet et al., 2003]. In May and June the maximum of the rainbelt is located around $5^{\circ} \mathrm{N}$, and, after a pause in late June/early July, it shifts northward to around $8^{\circ} / 10^{\circ} \mathrm{N}$, until mid September. In August, at the peak of the monsoonal season, the northernmost edge of the rainbelt is around $18^{\circ} \mathrm{N}$. The two datasets show similar rainfall amounts in JAS, although CMAP values are larger than GPCP in May-June. The ARPEGE model (Fig. 5a) reproduces the WAM seasonal cycle, with comparable rainfall amounts in June-September, it overestimates rainfall in May and it shows, in early June, an anticipation of the pause occurring before the inland installation of the monsoon. The ECHAM model (Fig. 5b) generally underestimates the JAS rainfall, with higher amounts in May-June, it does not reproduce the pause in June, and it shows a progressive northward penetration of the monsoon 
(with no abrupt northward shift), while the retreat in September is not well reproduced. By contrast, the UCLA model (Fig. 5c) largely overestimates the observations, simulates a pause before the inland shift in mid June, and locates the JAS rainfall maximum around $12^{\circ} \mathrm{N}$. However observations are partly reproduced in the ensemble-mean (Fig. 5d), since the UCLA and ARPEGE model overestimations well balance the too weak signal coming from the ECHAM model.

The observed $850 \mathrm{hPa}$ zonal wind shows the change in the low-levels circulation from the easterly regime to the westerly monsoonal flow in June, up to $15^{\circ} \mathrm{N}$ and with a maximum at the peak of the rainy season in July-August (Fig. 6i). The ensemble-mean reproduces the seasonal cycle and the intensity of the westerly flow (Fig. 6g), except in May, when positive values are observed as a consequence of the ARPEGE and UCLA anticipation of the flow change (Fig. 6ae). ECHAM produces a weak monsoonal flow, balanced in the ensemble mean by the large UCLA overestimation (Fig. 6ce).

In the mid troposphere, the circulation is dominated by the African easterly jet (AEJ), generated by the meridional thermal gradient between the Equatorial Africa moist surface and the dry and hot Sahara desert. In boreal summer the AEJ, fully developed around $600 \mathrm{hPa}$ between $10^{\circ} \mathrm{N}$ and $15^{\circ} \mathrm{N}$, blows from $30^{\circ} \mathrm{E}$ to the Atlantic coast and concentrates rainfall maxima on its southern flank [Cook, 1999]. The observed seasonal cycle (Fig. 6j) is quite well reproduced in the ensemble-mean (Fig. 6h), even if the mean position is northward shifted because of the ECHAM and UCLA responses (Fig. 6df). Also the intensity is underestimated due to the ARPEGE and ECHAM weak responses (Fig. 6bd).

\subsection{WAM precipitation and onset dates}

The ensemble-mean response of model precipitation to SST forcing over the Mediterranean sea is 
now presented through time-latitude diagrams of the warm-cold composite (Fig. 7). The rainfall is averaged in two zonal domains, $\left[10^{\circ} \mathrm{W}-10^{\circ} \mathrm{E}\right]$ and $\left[10 \mathrm{E}^{\circ}-30^{\circ} \mathrm{E}\right]$, after removing the synoptic variability ( $<10$ days). The longitudinal domains have been chosen in order to separate the region in which the sea-land thermal gradient and the monsoonal circulation develop approximatively in the meridional direction (west of $10^{\circ} \mathrm{E}$ ). We first verify that, as in the observations [Sultan et al. 2003], the individual simulations present a typical 15 day variability around $5^{\circ} \mathrm{N}$ in May-June and around $10^{\circ} \mathrm{N}$ in JAS, since out-of-phase combinations in ensemble-means and composites tend to suppress intraseasonal periodicities (Fig. 7). Rainfall anomalies are often positive, from May to September, from the Equator to $20^{\circ} \mathrm{N}$, with significant wet differences over western Sudan-Sahel in August-September (Fig. 7a; Tab. 3), also observed in each individual model, and eastward in late July, August and September (Fig. 7b; Tab. 3): the mean response is here dominated by the UCLA model (not shown).

The WAM onset has been defined by Sultan and Janicot [2003] as the abrupt latitudinal shift of the ITCZ from its quasi-stationary May-June position around $5^{\circ} \mathrm{N}$ to the JAS quasi-stationary position around $10^{\circ} \mathrm{N}$. Using OLR data in the period 1968-1990, they found that the WAM onset occurs in mean on June $24^{\text {th }}$, with an 8 day standard deviation (STD). Moreover, the end of June has been confirmed as the period for the mean occurrence of the WAM onset by Fontaine et al. [2008], using another OLR-based methodology, and by Dalu et al. [2009], using a hydrological index. A precipitation-based onset index has been also developed by Fontaine and Louvet [2006]. They defined a northern index (NI) by averaging the precipitation in the domain $\left[10^{\circ} \mathrm{W}-10^{\circ} \mathrm{E} ; 7.5^{\circ} \mathrm{N}\right.$ $20^{\circ} \mathrm{N}$ ] and a southern index (SI) in the domain $\left[10^{\circ} \mathrm{W}-10^{\circ} \mathrm{E} ; 0^{\circ}-7.5^{\circ} \mathrm{N}\right]$, and a WAM onset index (WAMOI) as the standardized NI minus SI difference, after eliminating the synoptic variability using a 15 day low-pass Butterworth filter. WAMOI increases (decreases) when the rainbelt migrates northward (southward) and the onset date is defined as the first pentad of a 20 day (or longer) period registering positive values of WAMOI, in order to determine a robust installation of 
the rainfall north of $7.5^{\circ} \mathrm{N}$. Using the CMAP and GPCP pentad data, they found 28-29 June with a 8.5 day STD as the mean onset date for the period 1979-2004.

The onset dates in numerical simulations are estimated using the WAMOI (Tab. 2). The WAMOI is computed for each run, then the mean and STD are computed. It is noteworthy the substantial agreement between the models despite a general anticipation of the onset date: June $18^{\text {th }}$ for the control run ensemble-mean, with a 5.9 day STD. WAM onset dates in sensitivity experiments are delayed in both warm and cold simulations, with a "warm onset" occurring later than a "cold onset”. In the ARPEGE model the mean onset occurs earlier than in the ECHAM and UCLA models, but the shifts are not significant, except for a later "warm onset" in the UCLA model (June $29^{\text {th }}$ with 5.3 day STD). The ensemble-mean shows no significant difference between the warm and cold simulations.

\subsection{Atmospheric dynamics}

\subsubsection{Low and mid troposphere circulation}

The low troposphere circulation over the Mediterranean/North Africa region in summer is under the influence of the Azores system [Meteorological Office, 1962; Lionello et al., 2006], which produces an anticyclonic circulation to the west centred over the Maghreb; and of the Indian monsoon [Rodwell and Hoskins, 2001], which produces a cyclonic circulation and an equatorward flow to the east over the Middle East and the Levantine basin (Fig. 2a). This northerly wind regime, known as Etesian or Meltemi [Meteorological Office, 1962], is the geostrophic wind produced by the pressure gradient between eastern and western Mediterranean. It can be considered as the local low level branch of the northern Hadley meridional circulation connecting the Mediterranean basin and the ITCZ over Africa. Raicich et al. [2003] found statistical evidences that the Etesian winds regime 
teleconnects the Indian monsoon and the Sahel monsoonal rainfall. Computing the Mediterranean pressure index (MPI) as the SLP standardized difference at the stations of Mersa Matruh (Egypt) and Marseille (France), i.e., between the cyclonic and anticyclonic circulations, they showed that when the Indian monsoon is stronger than normal, a negative SLP anomaly affects the eastern Mediterranean, enhancing the Mediterranean pressure gradient and reinforcing the northerly flow east of $15^{\circ} \mathrm{E}$. The consequent strengthened northerly flow favors change in low level convergence over Sahel with the contribution of the strengthening of the southwesterly monsoonal flow. We hypothesize that the prescribed SST anomalies over the Mediterranean sea have a sizeable influence on the Mediterranean SLP, modifying the circulation in the lower troposphere. In order to assert it, we compute the MPI as the difference between the SLP in the eastern basin $\left[15^{\circ} \mathrm{E}-35^{\circ} \mathrm{E} ; 30^{\circ} \mathrm{N}\right.$ $\left.40^{\circ} \mathrm{N}\right]$ and in the western basin $\left[5^{\circ} \mathrm{W}-15^{\circ} \mathrm{E} ; 35^{\circ} \mathrm{N}-45^{\circ} \mathrm{N}\right]$. Similar indices have been used in the past as representative of the differences in the behaviour of the eastern and western Mediterranean, in terms of temperature field and hydrological cycle [Conte et al., 1989; Palutikov et al., 1996; Palutikov, 2003]. In our case a negative value of the index, corresponding to a negative pressure gradient toward the eastern Mediterranean, is related to a northerly wind. The behaviour of the MPI is strongly related to the seasonal evolution of the SST forcing field, in which the eastern basin is warmer than the western (Fig. 4). In warm-cold composites from the ensemble-mean (Tab. 3), the MPI anomaly shows negative values in JAS, with significant values in the first half of September. In individual models, MPI warm-cold composites are significantly negative in June-July (UCLA model) and in September (ECHAM model), while the ARPEGE model produces a significant positive anomaly in late August (not shown). Such an increased pressure gradient is related to reinforced convergence in the Sahelian belt. Indeed, even though the MPI anomaly is significant only at the beginning of September, the dynamical response in the ensemble-mean is sizeable from August to mid September, with significant convergence anomalies at $850 \mathrm{hPa}$ over the eastern Sahel (Tab. 3). 
A warmer Mediterranean sea suggests the presence of additional moisture coming from the increased evaporation, mainly located in the lower troposphere. This statement is verified computing the time-latitude diagram of the specific humidity at $850 \mathrm{hPa}$ for the warm-cold composite. In the ensemble-mean, moisture anomalies are positive both in the western and eastern domains, from May to September. West of $10^{\circ} \mathrm{E}$, this is mainly observed between $20^{\circ} \mathrm{N}$ and $40^{\circ} \mathrm{N}$ from mid July to mid September, and between $10^{\circ} \mathrm{N}$ and $20^{\circ} \mathrm{N}$ in August-September (Fig. 8a; Tab. 3). East of $10^{\circ} \mathrm{E}$, this occurs over the eastern Mediterranean over the whole season, and between $15^{\circ} \mathrm{N}$ and $30^{\circ} \mathrm{N}$ from late June to September (Fig. $8 \mathrm{~b}$ ).

A good indicator of the monsoonal activity is the vertical integrated moisture transport (VIMT; Fasullo and Webster [2003]; Dalu et al. [2009]). In the Mediterranean/North Africa region it is defined as

$$
\text { V I M } \int_{8}^{1} \underset{5}{0} \frac{0}{q U} \frac{d}{\rho g},
$$

where $q$ is the specific humidity, $\mathbf{U}$ is the vector wind, $p$ is the pressure, $g$ is the gravity acceleration and $\rho$ is the air density, considered constant in the lower levels $\left(\rho=1 \mathrm{~kg} / \mathrm{m}^{3}\right)$. The warm-cold differences of the VIMT divergence show that there is no strong coherency over the western domain, except for a significant convergence anomaly around $20^{\circ} \mathrm{N}$ at the turn of August/September (Fig. 8c), while, over the eastern domain we notice a divergence above the Mediterranean sea from May to September, and a significant convergence anomaly (Fig. 8d; Tab. 3) over the Sahel from late July to mid September.

The role of the moisture transport from the Mediterranean in determining the convergence anomalies in the Sahel is discussed through the warm-cold differences of the $850 \mathrm{hPa}$ wind and VIMT fields, averaged in 15 day sub-periods between July and September (Fig. 9). When the VIMT field is considered, a persistent anomalous northerly flow from the eastern Mediterranean reaches 
the eastern Sahel, with maxima in the first half of August and September (Fig. 9fj). Furthermore, a reinforced southwesterly flow from the Atlantic ocean in August and September (Fig. 9fhjl) contributes to the anomalous moisture convergence in the eastern Sahel (Fig. 8d). On the other hand, significant wind anomalies in the southwesterly flow from the Atlantic are observed, while the northerly wind from the Mediterranean is unchanged or reduced (Fig. 9egik). Therefore, the moisture transport from both the Atlantic ocean and the Mediterranean sea contribute to the convergence over the Sahel, the former reinforced by the increased wind field, the latter by the augmented specific humidity.

The AEJ changes induced by the SST forcing are shown through the $600 \mathrm{hPa}$ zonal wind warm-cold differences averaged between $10^{\circ} \mathrm{W}$ and $30^{\circ} \mathrm{E}$, displayed in Fig. 10. From mid July to September, negative differences are observed between $15^{\circ} \mathrm{N}$ and $20^{\circ} \mathrm{N}$, with significant values in late July, midAugust and September showing that when the Mediterranean is warmer than average, the AEJ is shifted northward.

\subsubsection{African easterly waves}

At synoptic scale, the West African convection is modulated by the AEWs (3-5 day and 6-9 day periodicity, around $5^{\circ} \mathrm{N}$ and $15^{\circ} \mathrm{N}$, respectively), during the boreal summer, mainly in AugustSeptember [Diedhiou et al., 1999]. We use the variance of the $700 \mathrm{hPa}$ meridional wind filtered at 2-10 day [Sylla et al., 2009] as a descriptor of the wave activity, and we test the effect of Mediterranean SST anomalies on the AEWs in August-September, after evaluating the numerical capability to reproduce AEWs mean activity. In fact ARPEGE and UCLA models reproduce part of the observed AEWs features. In August, the ensemble-mean signal is in the lee of the Ethiopian plateau and of the Ahaggar massif (Fig. 11ac), while, in September it is generally weaker and shifted southward to $5^{\circ} \mathrm{N}$ and northward to $20^{\circ} \mathrm{N}$, respectively (Fig. 11eg). 
The models response has been evaluated through the 'one model one vote' concept [Santer et al., 2009]. It consists in computing over the successive 15 day sub-periods of the bi-month AugustSeptember, the number of positive/negative occurrences in warm-cold differences, for each model and each run, $3 \times 10=30$ events. Therefore, the wave activity response can be defined by calculating at each grid point, a simple score ranging either between +16 and +30 or between -16 and -30: +16 (-16) means that 16 models out of 30 simulate an increasing (a decreasing) signal in wave activity, and $+30(-30)$ that all models produce an excess (a deficit) in this activity. The significance is then evaluated considering the field response in each sub-period: the response is significantly positive (negative) in the sub-period if the percentage of positive (null or negative) grid points in the field is significantly greater than 50\% regarding a binomial distribution with only 30 degrees of freedom (confidence interval [33\% 66\%]). The ensemble warm-cold differences show a significant positive response (71\% of positive occurrences) in the first half of August, with a large belt of increased wave activity between $5^{\circ} \mathrm{N}$ and $25^{\circ} \mathrm{N}$ (Fig. 11b). Notice also that after mid August the global field significance decreases (59\%) except in the western domain where the wave activity continues (Fig. 11d). By contrast, in September (first and second half field significance 53\% and $41 \%$, respectively) and over the eastern domain (Fig. 11fh), this activity tends to augment in consistency with increased convergence over eastern Sahel (Tab. 3).

\subsection{WAM energetics}

Models response to a warmer Mediterranean produces a moisture transport over the Sahara toward the Sahel in August-September (Fig. 8; Tab. 3), affecting the energy budget of the monsoon. Over the Sahara desert, the circulation is influenced by the shallow dry convection related to the diabatic heating in the Saharan heat-low (SHL) in the low troposphere, and by the Saharan high related to the diabatic cooling at higher levels. This circulation contributes to the maintenance of the AEJ 
through the Coriolis acceleration associated to the divergent northerlies flowing between the SHL and the Saharan high [Chen, 2005]. Furthermore, it is important to evaluate the moist static energy (MSE) meridional gradient near the surface which forces the monsoon circulation and its inland excursion, since, as shown by Eltahir and Gong [1996], a stronger (weaker) gradient drives stronger (weaker) monsoonal circulation and northward excursion. In this paragraph we discuss the position and thickness of the SHL and the MSE meridional gradient at $1000 \mathrm{hPa}$ over West Africa in the warm-cold composites.

Lavaysse et al. [2009] studied the SHL behaviour by computing the geopotential height differences between two levels (700hPa and 925hPa) and detected its location by searching the maximum, i.e., where the thermally induced dilatation of low atmospheric levels is largest. In summer the SHL climatological position is between the Ahaggar and the Atlas. The warm-cold differences observed in the ensemble-mean show a general north-eastward migration with significant values during particular subperiods of the rainy season: up to $5^{\circ}$ in longitude in late July, up to $7^{\circ}$ in longitude and $7^{\circ}$ in latitude in late August and up to $8^{\circ}$ in longitude in late September (Fig. 12a; Tab. 3). This is associated with a significant thickness increase in August-September (Fig. 12b; Tab. 3). The changes in the SHL are consistent with the northward shift and intensification of the AEJ (Fig. 10) and with a more inland penetration of the monsoonal front and consequent wet anomalies over western Sahel (Fig. 7a).

The MSE is defined as

$$
M \quad \mathcal{S} g E \forall C_{p} T+L
$$

where $z$ is the geopotential height, $C_{p}$ the specific heat of dry air at constant pressure, $T$ the temperature, $L$ the latent heat of evaporation and $q$ the specific humidity. Regional contents are estimated by averaging the MSE at $1000 \mathrm{hPa}$ over four domains: Atlantic $\left[15^{\circ} \mathrm{W}-15^{\circ} \mathrm{E} ; 0^{\circ} \mathrm{N}-5^{\circ} \mathrm{N}\right.$, Guinea $\left[15^{\circ} \mathrm{W}-15^{\circ} \mathrm{E} ; 5^{\circ} \mathrm{N}-10^{\circ} \mathrm{N}\right]$, Sudan $\left[15^{\circ} \mathrm{W}-15^{\circ} \mathrm{E} ; 10^{\circ} \mathrm{N}-15^{\circ} \mathrm{N}\right]$, Sahel $\left[15^{\circ} \mathrm{W}-15^{\circ} \mathrm{E} ; 15^{\circ} \mathrm{N}-\right.$ 
$20^{\circ} \mathrm{N}$ ]. Differences between these adjacent domains are computed following the northward direction in order to approximate the MSE meridional gradient between the main belts: the Atlantic and the Guinean domains (Guinea-Atlantic difference), the Guinean and Sudanian regions (Sudan-Guinea) and the Sudanian and Sahelian belts (Sahel-Sudan). In the ensemble-mean, warm-cold differences in the Guinea-Atlantic gradient are weak (Fig. 13d). By contrast the MSE gradients are reinforced, while northward, in JAS, with significant values from mid August to mid September (Fig. 13bc). This is also observed when the land-sea contrast is taken into consideration: the Sahel-Atlantic MSE differences augment in July, and are significant in early August (Fig. 13a; Tab. 3). Those reinforcements, directly linked to a warmer Mediterranean, are a consequence of the moisture supply provided over the western domain in August-September (Fig. 8a and Fig. 9) and consistent with the intensification of the precipitation in August-September (Fig. 7a). Since the positive moisture anomaly peaks around $15^{\circ} \mathrm{N}$, the reinforced Sudan-Guinea MSE gradient is also larger than local anomalies.

\section{Summary and conclusions}

In the present paper we explored the seasonal cycle of the WAM-Mediterranean relationship and focused on the intraseasonal variability using the R-2 surface and atmospheric variables, the CMAP and GPCP rainfall estimates and results from numerical forced experiments performed using three AGCMs: ARPEGE, ECHAM, UCLA.

The observed WAM-Mediterranean interannual relationship over the period 1979-2007 has been investigated by analysing the Mediterranean surface temperatures, the rainfall over West Africa, the specific humidity and the wind field in order to better understand the associated atmospheric dynamics. The first SVD mode confirms the statistical relationship between the two domains mainly when the monsoon is fully developed over the Sudano-Sahelian belt. The warm-cold 
composites show that a warmer eastern Mediterranean produces a low pressure anomaly near the surface and feeds the lower troposphere with moisture: this generates a SLP gradient between the eastern and western basins which reinforces the low-levels northeasterly geostrophic flow towards the Sahara, transports additional moisture and favours moisture convergence in the WAM area along with its inland penetration from the Atlantic. Accordingly with Rowell [2003], Raicich et al. [2003], Jung et al. [2006], Fontaine et al. [2010], a warm Mediterranean sea positively affects the monsoonal precipitation over the Sudano-Sahelian belt in July-September.

The May to September model outputs of experiments with prescribed warm/cold SST anomalies over the Mediterranean have been also analysed, showing a seasonal modulation: the second half of the monsoon season (August-September), is more affected by the Mediterranean SST anomalies. In short the succession of events is as follows. Warmer SSTs over the Mediterranean generate in July positive moisture anomalies due to increased evaporation. These anomalies reinforce in August and September and the higher moisture amount is advected by the northerlies (Etesian winds) across the Sahara desert toward the eastern Sahel. Moisture convergence over the monsoonal region is thus thermodynamically reinforced, with the contribution of a strengthened southwesterly monsoonal flow, while enhanced convection increases the AEWs activity across the Sudano-Sahelian belt in August. Over the western Sahel the behaviour of the SHL and of the MSE meridional gradient have been also analysed since part of anomalous moisture reaches West Africa north of $10^{\circ} \mathrm{N}$ after mid August, which affects the SHL and the MSE low-levels content. The response is a reinforcement and a northward shift of the SHL and an increase of the MSE gradient between the Sudan-Sahel and the Guinea coast, favouring rainfall excess in western Sahel. The resulting northward shift of the AEJ, consistent with the meridional displacement of the rainbelt, is related to changes in divergent circulation between the SHL and the Saharan high. Thus, in the eastern Sahel the rainfall anomalies from late July to the end of September are related to the additional moisture available, which is advected from the Mediterranean, and to the dynamical reinforcement of the monsoonal front. In 
the western Sahel rainfall excesses from early August to the end of September are related to the more inland penetration of the WAM rainbelt, the additional moisture producing here a clear northward shift of the monsoon air.

The simulated monsoonal precipitation and dynamical responses in the models are closely linked to the SST forcing evolution but are not synchronous. Anomalies in the MPI start in July, when the eastern Mediterranean basin is slightly warmer than the western basin. Interestingly they do not reach any significant values before September, i.e., when the east-west SST gradient is stronger, although the convergence effects in the eastern Sudan-Sahel are sizeable since the beginning of August. A difference between observations and simulations arises: in the R-2 data, warm Mediterranean anomalies are liked to a significant intensification of the Etesian winds and moisture transport from the Mediterranean; while in the sensitivity experiments, the northerly moisture transport is strengthened by the additional moisture availability, with no significant changes in the wind from the Mediterranean. Changes in the R-2 northerly wind are consistent with the MPIEtesian dynamics observed by Raicich et al. [2003] and they can be related to the variability of the Indian monsoon circulation, while moisture transport anomalies are directly related to the warming of the Mediterranean sea. This feature is confirmed by the sensitivity experiments, in which the Mediterranean forcing is not capable to induce significant changes in the MPI, whereas it supplies additional moisture, inducing large anomalies in the northerly moisture transport. So we make the hypothesis that rainfall anomalies in eastern Sudan-Sahel occur in late July as a consequence of the moisture-Etesian dynamics, while in western Sudan-Sahel they occur in early August in relation to this additional moisture transport favouring the inland penetration of the monsoon, through the intensification of the SHL and the reinforcement of the MSE meridional gradient. The contemporary strengthening of the southwesterly monsoonal flow suggests that the Mediterranean sea acts positively on the Sudan-Sahel precipitation when the thermodynamical processes are fully developed inland in the monsoon air. 


\section{Acknowledgement}

NCEP Reanalysis data are provided by the NOAA-CIRES ESRL/PSD Climate Diagnostics branch, Boulder, Colorado, USA (http://www.esrl.noaa.gov/). The GPCP data were developed and computed by the NASA/Goddard Space Flight Center's Laboratory for Atmospheres as a contribution to the GEWEX Global Precipitation Climatology Project. CMAP Precipitation data provided by the NOAA/OAR/ESRL PSD, Boulder, Colorado, USA, from their Web site at http://www.esrl.noaa.gov/psd/. This study was supported by the TELEMEDAF (Italian CNR / French CNRS joint project) and by the European Union AMMA-FP6 project. Based on the French initiative, AMMA was built by an international scientific group and is currently funded by a large number of agencies, especially from France, the United Kingdom, the United States, and Africa. It has been the beneficiary of a major financial contribution from the European Community's Sixth Framework Research Programme. (Detailed information on scientific coordination and funding is available on the AMMA International Web site, http://www.amma-international.org.).

\section{References}

Baldi, M., G.A. Dalu, G. Maracchi, M. Pasqui, and F. Cesarone (2006), Heat-waves in the Mediterranean: a local feature or a larger scale effect? Int. J. Climatol., 26, 1477-1487.

Chen, T.H. (2005), Maintenance of the Midtropospheric North African Summer Circulation: Saharan High and African Easterly Jet, J. Climate, 18, 2943-2962.

Conte, M., A. Giuffrida, and S. Tedesco (1989), The Mediterranean oscillation. Impact on precipitation and hydrology in Italy, in Conference on Climate and Water, vol. 1, pp. 121-137, publication of the Academy of Finland, Helsinki.

Cook, K. H. (1999), Generation of the African easterly jet and its role in determining West African 
precipitation, J. Climate, 12, 1165-1184.

Dalu, G. A., M. Gaetani, and M. Baldi (2009), A hydrological onset and withdrawal index for the West African monsoon, Theor, Appl. Climatol., 96, 179-189, doi:10.1007/s00704-008-0022-8.

Déqué, M., C. Dreveton, A. Braun, and D. Cariolle (1994), The ARPEGE/IFS atmosphere model: A contribution to the French community climate modelling, Clim. Dyn., 10, 249-266.

Diedhou, A., S. Janicot, A. Viltard, P. de Felice, and H. Laurent (1999), Easterly wave regimes and associated convection over West Africa and tropical Atlantic: Results from the NCEP/ NCAR and ECMWF reanalyses, Clim. Dyn., 15, 795-822.

Eltahir, A.B., and C. Gong (1996), Dynamics of wet and dry years in West Africa, J. Climate, 9, 1030-1042.

Fasullo, J., and P. J. Webster (2003), A Hydrological Definition of Indian Monsoon Onset and Withdrawal, J. Climate, 16, 3200-3211.

Fontaine, B., and S. Louvet (2006), Sudan-Sahel rainfall onset: Definition of an objective index, types of years, and experimental hindcasts, J. Geophys. Res., 111, D20103, doi:10.1029/2005JD007019.

Fontaine, B., P. Roucou, and S. Trzaska (2003), Atmospheric water cycle and moisture fluxes in the West African monsoon: mean annual cycles and relationship using NCEP/NCAR reanalyses, Geophys. Res. Lett., 30, doi:10.1029-10.1032.

Fontaine, B., S. Louvet, and P. Roucou (2008), Definition and predictability of an OLR based West African monsoon onset, Int. J. Climatol., 28, 1787-1798, doi:10.1002/joc.1674.

Fontaine, B., J. Garcia-Serrano, P. Roucou, B. Rodriguez-Fonseca, T. Losada, F. Chauvin, S. Gervois, S. Sijikumar, P. Ruti, and S. Janicot (2010), Impacts of warm and cold situations in the Mediterranean basins on the West African monsoon: observed connection patterns (1979-2006) and climate simulations, Clim. Dyn., 35, 95-114, doi:10.1007/s00382-009-0599-3.

Gates, W. L. (1993), AMIP: The Atmospheric Model Intercomparison Project, Bull. Amer. Meteor. Soc., 73, 1962-1970. 
Giannini, A., R. Saravanan, and P. Chang (2003), Oceanic forcing of Sahel rainfall on interannual to interdecadal time scales, Science, 302, 1027-1030.

Gu, G., and R. F. Adler (2004), Seasonal Evolution and Variability Associated with the West African Monsoon System, J. Climate, 17, 3364-3377.

Gu, G., R. F. Adler, G. J. Huffman, and S. Curtic (2004), African easterly waves and their association with precipitation, J. Geophys. Res., 109, D04101, doi:10.1029/2003JD003967.

Janicot, S., S. Trzaska, and I. Poccard (2001), Summer Sahel-ENSO teleconnection and decadal time scale SST variations, Clim. Dyn., 18, 303-320.

Janicot, S., F. Mounier, N. M. J. Hall, S. Leroux, B. Sultan, and G. N. Kiladis (2009), The dynamics of the West African monsoon. Part IV: Analysis of 25-90-day variability of convection and the role of the Indian monsoon, J. Climate, 22, 1541-1565.

Joly, M. (2008), Rôle des océans dans la variabilité climatique de la mousson Africaine, Ph.D. Thesis, Université Toulouse III, Toulouse, France.

Joly, M., and A. Voldoire (2009), Role of the Gulf of Guinea in the inter-annual variability of the West African monsoon: what do we learn from CMIP3 coupled simulations? Int. J. Climatol., 10.1002/joc.2026.

Jung, T., L. Ferranti, and A. M. Tompkins (2006), Response to the Summer of 2003 Mediterranean SST Anomalies over Europe and Africa, J. Climate, 19, 5439-5454.

Kanamitsu, M., W. Ebisuzxaki, J. Woolen, S.K. Yang, J. Hnilo, M. Fiorino, and G.L. Potter (2002), NCEP-DOE AMIP-II Reanalysis (R-2), Bull. Amer. Meteor. Soc., 83, 1631-1643.

Lavender, S.L., and A. J. Matthews (2009), Response of the West African Monsoon to the MaddenJulian Oscillation, J. Climate, 22, 4097-4116.

Lavaysse, C., C. Flamant, S. Janicot, D.J. Parker, J.P. Lafore, B. Sultan, and J. Pelon (2009), Seasonal evolution of the West African heat low: a climatological perspective, Clim. Dyn., 33, 313-330, doi:10.1007/s00382-009-0553-4.

Lebel, T., and A. Ali (2009), Recent trends in the Central and Western Sahel rainfall regime (1990- 
2007), J. Hydrology, 375, 52-64.

Lionello, P., P. Malanotte-Rizzoli, and R. Boscolo (Eds) (2006), Mediterranean Climate: an overview of the main characteristics and issues, Elsevier, Amsterdam, The Netherlands.

Losada, T., B. Rodrìguez-Fonseca, S. Janicot, S. Gervois, F. Chauvin, and P. Ruti (2009), A multimodel approach to the Atlantic Equatorial mode: impact on the West African monsoon, Clim. Dyn., doi:10.1007/s00382-009-0625-5.

Louvet, S., B. Fontaine, and P. Roucou (2003), Active phases and pauses during the installation of the West African monsoon through 5-day CMAP rainfall data (1979-2001), Geophys. Res. Lett., 30, 2271, doi:10.1029/2003GL018058.

Mathon, V., H. Laurent, and T. Lebel (2002), Mesoscale convective system rainfall in the Sahel, $J$. Appl. Meteor., 41, 1081-1092.

Meteorological Office (1962), Weather in the Mediterranean, pub. 391, vol. 1, General Meteorology, London, UK.

Murakami, M. (1979), Large scale aspects of deep convective activity over the Gate area, Mon. Wea. Rev., 107, 994-1013.

Palutikov, J.P. (2003), Analysis of Mediterranean climate data: measured and modelled, in Mediterranean climate: variability and trends, edited by Bolle, H.J., pp. 125-132, SpringerVerlag, Berlin, Germany.

Palutikov, J.P., M. Conte, J. Casimiro Mendes, C.M. Goodess, and F. Espirito Santo (1996), Climate and Climate Change, in Mediterranean desertification and land use, edited by Brandt, C.J., and J.B. Thornes, pp. 43-86, John Wiley and Sons, London, UK.

Peyrille, P., and J.P. Lafore (2007), An idealized two-dimensional framework to study the West African monsoon. Part II: Large-scale advection and the diurnal cycle, J. Atmos. Sci., 64, 27832803.

Peyrillé, P., J.P. Lafore, and J.L. Redelsperger (2007), An idealized two-dimensional framework to study the West African Monsoon. Part I: validation and key controlling factors, J. Atmos. Sci., 
64, 2765-2782.

Polo, I., B. Rodríguez-Fonseca, T. Losada, and J. García-Serrano (2008), Tropical Atlantic Variability modes (1979-2002). Part I: time-evolving SST modes related to West African rainfall, J. Climate, 21, 6457-6475.

Raicich, F., N. Pinardi, and A. Navarra (2003), Teleconnections between Indian Monsoon and Sahel rainfall and the Mediterranean, Int. J. Climatol., 23, 173-186.

Redelsperger, J.L., C.D. Thorncroft, A. Diedhiou, T. Lebel, D.J. Parker, and J. Polcher (2006), African Monsoon Multidisciplinary Analysis: An International Research Project and Field Campaign, Bull. Amer. Meteor. Soc., 87, 1739-1746, doi:10.1175/BAMS-87-12-1739.

Ritcher, I., C.R. Mechoso, and A.W. Robertson (2008), What determines the position and intensity of the south Atlantic anticyclone in Austral Winter? An AGCM study, J. Climate, 21, 214-229.

Rodwell, M.J., and B.J. Hoskins (2001), Subtropical anticyclones and summer monsoons, J. Climate, 14, 3192-3211.

Roeckner, E., K. Arpe, L. Bengtsson, M. Christoph, M. Claussen, L. Dumenil, M. Esch, M. Giorgetta, U. Schlese, and U. Schulzweida (1996), The atmospheric general circulation model ECHAM-4: model descriptions and simulation of present-day climate, Rep. 218, Max Planck Institute, Hamburg, Germany.

Rowell, D.P. (2003), The Impact of Mediterranean SSTs on the Sahelian Rainfall Season, J. Climate, 16, 849-862.

Santer, B.D., K.E. Taylor, P.J. Gleckler, C. Bonfils, T.P. Barnett, D.W. Pierce, T.M.L. Wigley, C. Mears, F.J. Wentz, W. Braggemann, N.P. Gillett, S.A. Klein, S. Solomon, P.A. Stott, and M.F. Wehner (2009), Incorporating model quality information in climate change detection and attribution studies, Proceedings of the National Academy of Sciences, 106, 14778-14783.

Smith, T.M., and R.W. Reynolds (2004), Improved extended reconstruction of SST (1854-1997), J. Climate, 17, 2466-2477.

Sultan, B., and S. Janicot (2003), The West African Monsoon Dynamics. Part II: The "Preonset” 
and “Onset” of the Summer Monsoon, J. Climate, 16, 3407-3427.

Sultan, B., S. Janicot, and A. Diedhiou (2003), The West African Monsoon Dynamics. Part I: Documentation of Intraseasonal Variability, J. Climate, 16, 21, 3389-3406.

Sultan, B., C. Baron, M. Dingkuhn, B. Sarr, and S. Janicot (2005), Agricultural impacts of largescale variability of the West African monsoon, Agric. For. Meteorol., 128, 93-110.

Sylla, M.B., A. Dell’Aquila, P.M. Ruti, and F. Giorgi (2009), Simulation of the intraseasonal and the interannual variability of rainfall over West Africa with RegCM3 during the monsoon period, Int. J. Climatol., doi:10.1002/joc.2029.

von Storch, H., and F.W. Zwiers (1999), Statistical Analysis in Climate Research, Cambridge University Press, Cambridge, UK.

Xie, P., and P.A. Arkin (1997), Global precipitation: A 17-year monthly analysis based on gauge observations, satellite estimates, and numerical model outputs, Bull. Americ. Meteor. Soc., 78, 2539-2558.

Xie, P., J.E. Janowiak, P.A. Arkin, R.F. Adler, A. Gruber, R.R. Ferraro, G.J. Huffman, and S. Curtis (2003), GPCP Pentad Precipitation Analyses: An Experimental Dataset Based on Gauge Observations and Satellite Estimates, J. Climate, 16, 2197-2214. 


\section{Figures captions}

Figure 1: SVD analysis for the Mediterranean skin temperature and the WAM precipitation. (a,b) Heterogeneous correlation maps for the MJ $1^{\text {st }}$ SVD mode and related ECs time series for skin temperature (dash) and precipitation (solid). (c,d) same as (a,b) but in JAS. Contour interval is 0.1, correlation values significant at $90 \%$ are shaded.

Figure 2: 1979-2007 JAS climatology of (a) $850 \mathrm{hPa}$ and (b) $200 \mathrm{hPa}$ wind (m/s). JAS warm-cold Mediterranean composite of (c) $850 \mathrm{hPa}$ and (d) $200 \mathrm{hPa}$ wind (m/s). Bold arrows are the differences $90 \%$ significant after a t-Student test; in brackets the percentages of field significance regarding a local test at $90 \%$.

Figure 3: 1979-2007 JAS climatology of (a) 850 hPa specific humidity (g/kg) and (b) $850 \mathrm{hPa}$ moisture transport (g/kg m/s). JAS warm-cold Mediterranean composite of (c) $850 \mathrm{hPa}$ specific humidity (g/kg) and (d) 850 hPa moisture transport (g/kg m/s). Shaded contours and bold arrows are the differences $90 \%$ significant after a t-Student test; in brackets the percentages of field significance regarding a local test at $90 \%$.

Figure 4: May to October forcing fields used in the AGCM warm experiments. SST anomalies are expressed in ${ }^{\circ} \mathrm{C}$ units.

Figure 5: May to September time-latitude diagram of the 10 years control run precipitation (mm/day) averaged between $10^{\circ} \mathrm{W}$ and $30^{\circ} \mathrm{E}$ for (a) ARPEGE4, (b) ECHAM4, (c) UCLA7.3 and (d) ensemble-mean, compared with the 1979-1988 (e) CMAP and (f) GPCP.

Figure 6: May to September time-latitude diagram of the 10 years control run zonal wind at 850 and 
$600 \mathrm{hPa}(\mathrm{m} / \mathrm{s})$ averaged between $10^{\circ} \mathrm{W}$ and $30^{\circ} \mathrm{E}$ for (a,b) ARPEGE4, (c,d) ECHAM4, (e,f) UCLA7.3 and (g,h) ensemble-mean, compared with the 1979-1988 (i,j) R-2.

Figure 7: May to September time-latitude diagram of the ensemble-mean precipitation (mm/day), warm-cold composite, averaged between (a) $10^{\circ} \mathrm{W}$ and $10^{\circ} \mathrm{E}$, and (b) $10^{\circ} \mathrm{E}$ and $30^{\circ} \mathrm{E}$; shaded contours are the differences $90 \%$ significant after a t-Student test; in brackets the percentages of field significance regarding a local test at $90 \%$.

Figure 8: May to September time-latitude diagram of the ensemble-mean 850 hPa specific humidity (g/kg) averaged between (a) $10^{\circ} \mathrm{W}$ and $10^{\circ} \mathrm{E}$, and (b) $10^{\circ} \mathrm{E}$ and $30^{\circ} \mathrm{E}$, warm-cold composite. May to September time-latitude diagram of the ensemble-mean VIMT divergence $\left(10^{6} \mathrm{~m} / \mathrm{s}\right)$ averaged between (c) $10^{\circ} \mathrm{W}$ and $10^{\circ} \mathrm{E}$, and (d) $10^{\circ} \mathrm{E}$ and $30^{\circ} \mathrm{E}$, warm-cold composite. Shaded contours are the differences $90 \%$ significant after a t-Student test; in brackets the percentages of field significance regarding a local test at $90 \%$.

Figure 9: July to September ensemble-mean 850 hPa wind (panels a, c, e, g, i, k) and VIMT (panels b, d, f, h, j, l), warm-cold composite averaged through 15 day sub-periods. The differences $90 \%$ significant after a t-Student test are displayed; in brackets the percentages of field significance regarding a local test at $90 \%$.

Figure 10: May to September time-latitude diagram of the ensemble-mean $600 \mathrm{hPa}$ zonal wind (m/s) averaged between $10^{\circ} \mathrm{W}$ and $30^{\circ} \mathrm{E}$, warm-cold composite. Shaded contours are the differences $90 \%$ significant after a t-Student test, in brackets the percentages of field significance regarding a local test at $90 \%$. 
Figure 11: AEWs: control runs ensemble-mean of the variance of the 700hPa meridional wind filtered in the 2-10 day band $\left(\mathrm{m}^{2} / \mathrm{s}^{2}\right)$, in (a,c) August and (e,g) September; positive and negative occurrences in warm-cold differences in (b,d) August and (f,h) September (see section 3.4.2 for more details on this score). In titles, the percentages of positive grid points in the domain and, in brackets, the confidence interval for a binomial distribution with 30 degrees of freedom and $90 \%$ significance are displayed.

Figure 12: May to September evolution of the ensemble-mean SHL (a) latitudinal (solid line) and longitudinal (dash line) location, and (b) thickness (m), warm-cold difference. Circles are the differences $90 \%$ significant after a t-Student test.

Figure 13: May to September evolution of the ensemble-mean 1000hPa MSE $\left(\mathrm{m}^{2} / \mathrm{s}^{2}\right)$ difference between (a) Sahel and Atlantic, (b) Sahel and Sudan, (c) Sudan and Guinea, and (d) Guinea and Atlantic domains, warm-cold composite. Circles are the differences $90 \%$ significant after a tStudent test. 


\section{Tables}

Table 1: Warm and cold JAS in the Mediterranean computed using the ECs of the first SVD mode skin temperature pattern. The years are sorted from the warmest and the coldest.

\begin{tabular}{cc}
\hline Warm Mediterranean & Cold Mediterranean \\
(ECs ${ }^{\text {rd }}$ tercile $)$ & (ECs ${ }^{\text {st }}$ tercile) \\
\hline 1994 & 1997 \\
1988 & 1996 \\
2003 & 1984 \\
1987 & 1992 \\
1986 & 2004 \\
2001 & 1993 \\
1982 & 2005 \\
1999 & 1991 \\
2007 & 1981 \\
\hline
\end{tabular}

Table 2: WAM onset dates and standard deviations in the Mediterranean experiments, control run, warm and cold experiments. The UCLA warm-control onset difference is $90 \%$ significant after a tStudent test (bold).

Model run ARPEGE ECHAM UCLA Ensemble

Control 18 Jun (6.8) 20 Jun (9.6) 23 Jun (3.4) 18 Jun (5.9)

Warm 22 Jun (5.2) 28 Jun (20.2) 29 Jun (5.3) 20 Jun (4.5)

Cold $\quad 21$ Jun (8.7) 25 Jun (11.1) 26 Jun (6.5) 20 Jun (5.2) 
Table 3: Warm-cold differences: July to September evolution of the main indices used in the text and averaged over 15 day sub-periods. Precipitation is averaged in $\left[10^{\circ} \mathrm{N}-20^{\circ} \mathrm{N}\right]$; $850 \mathrm{hPa}$ divergence is averaged in $\left[15^{\circ} \mathrm{N}-25^{\circ} \mathrm{N}\right]$; $850 \mathrm{hPa}$ moisture is averaged in $\left[15^{\circ} \mathrm{N}-30^{\circ} \mathrm{N}\right]$. The western domain is between $10^{\circ} \mathrm{W}$ and $10^{\circ} \mathrm{E}$, the eastern domain is between $10^{\circ} \mathrm{E}$ and $30^{\circ} \mathrm{E}$. Bold values are 90\% significant after a t-Student test.

\begin{tabular}{|c|c|c|c|c|c|c|}
\hline \multirow[b]{2}{*}{ Index } & \multicolumn{2}{|c|}{ JUL } & \multicolumn{2}{|c|}{ AUG } & \multicolumn{2}{|c|}{ SEP } \\
\hline & $1-15$ & $16-31$ & $1-15$ & $16-31$ & $1-15$ & $16-30$ \\
\hline Western Sudan-Sahel precip (mm/day) & +0.26 & +0.21 & +0.30 & +0.58 & +0.47 & +0.35 \\
\hline Eastern Sudan-Sahel precip (mm/day) & +0.29 & +0.44 & +0.47 & +0.42 & +0.39 & +0.26 \\
\hline $\operatorname{MPI}(\mathrm{Pa})$ & -61.0 & -36.2 & -28.5 & -5.2 & -99.3 & -40.3 \\
\hline Eastern Sudan-Sahel DIV $\left(10^{-6} \mathrm{~s}^{-1}\right)$ & -0.32 & -0.26 & -0.40 & -0.41 & -0.43 & -0.32 \\
\hline Eastern Sudan-Sahel DIV(VIMT) $\left(10^{-6} \mathrm{~m} / \mathrm{s}\right)$ & -6.35 & -4.48 & -10.45 & -11.18 & -8.42 & -4.73 \\
\hline Western Sahara-Sahel moisture (g/kg) & +0.50 & +0.43 & +0.66 & +0.84 & +0.76 & +0.37 \\
\hline SHL thickness (m) & -1.35 & 0.96 & +2.80 & +3.77 & +2.89 & +4.13 \\
\hline SHL migration (direction) & $\mathrm{W}$ & $\mathrm{S} \mathrm{E}$ & $\mathrm{NE}$ & $\mathrm{NE}$ & N W & $\mathrm{NE}$ \\
\hline Sahel-Atlantic MSE gradient $\left(\mathrm{m}^{2} / \mathrm{s}^{2}\right)$ & +1060 & +139 & +869 & +2405 & +1953 & +1056 \\
\hline
\end{tabular}



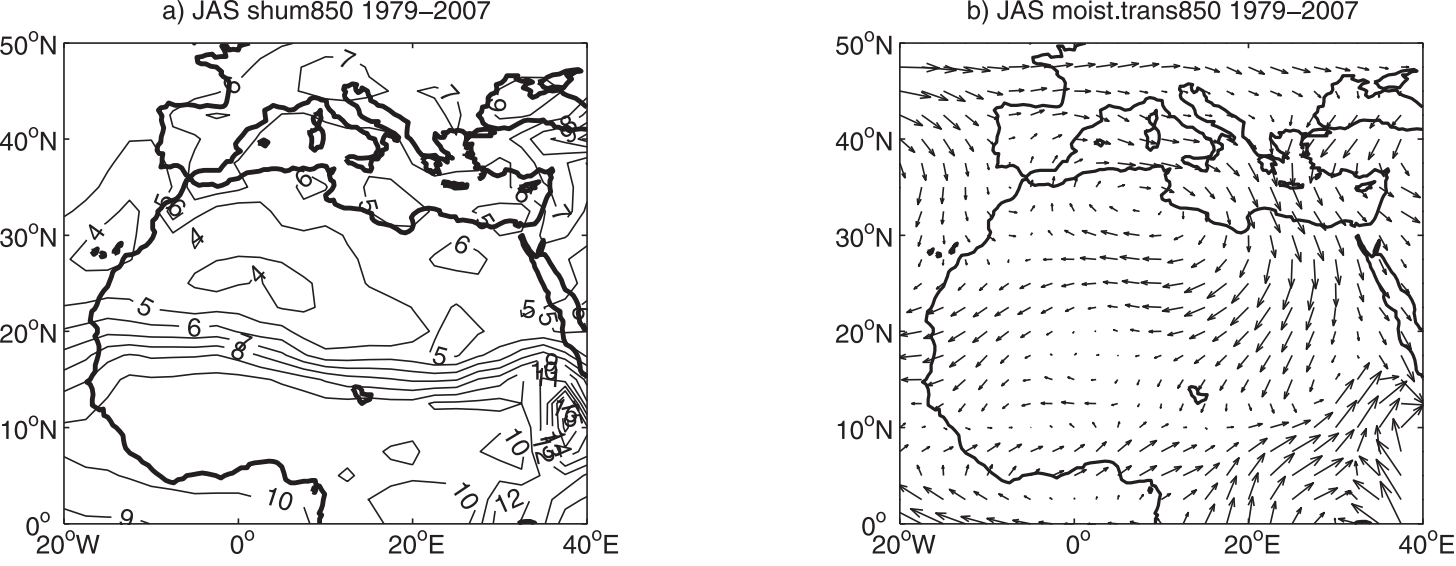

c) JAS shum850 WARM-COLD (loc.sig=0.19)

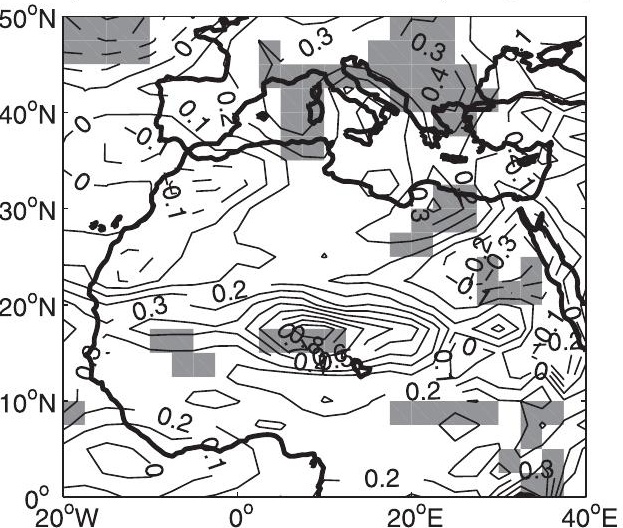

d) JAS moist.trans850 WARM-COLD (loc.sig=0.11)

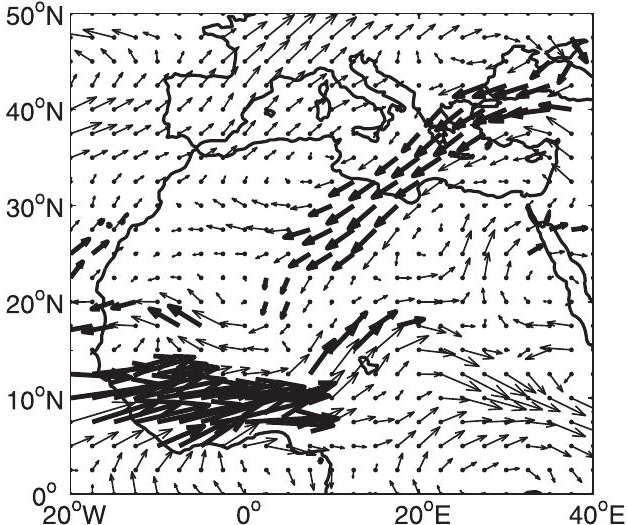


a) CNRM-ARPEGE3 10W-30E precip

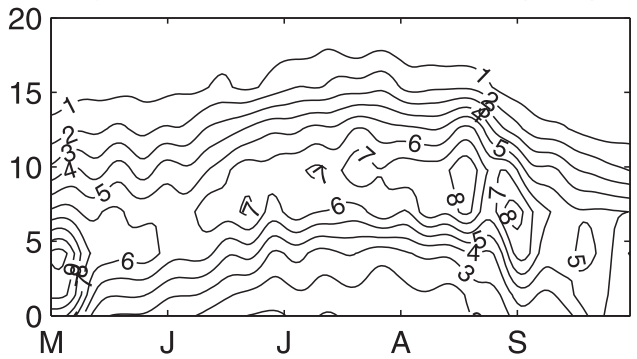

c) UCM-UCLA7.3 10W-30E precip
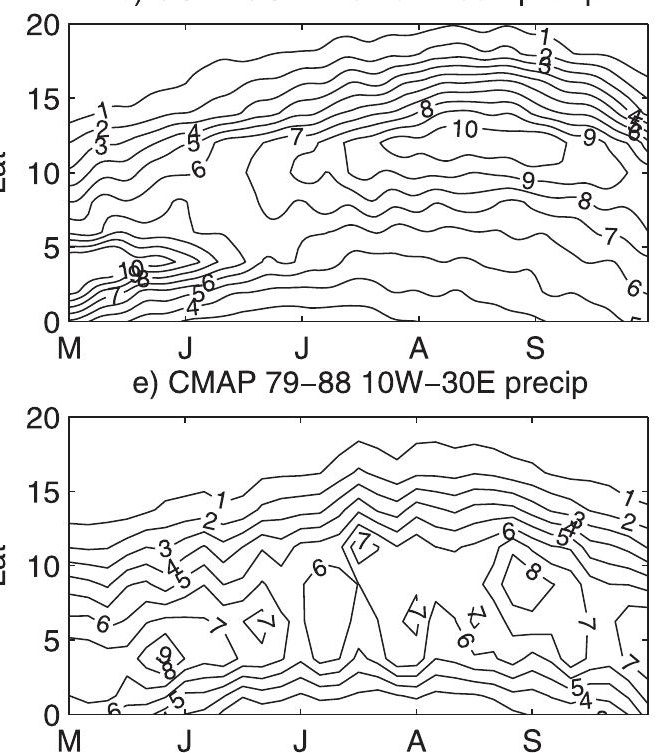

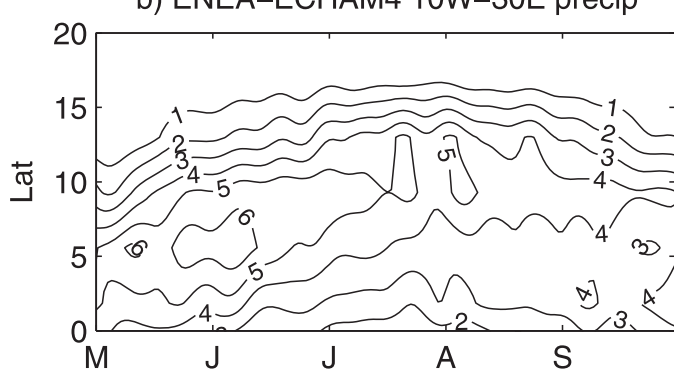

d) ENSEMBLE 10W-30E precip
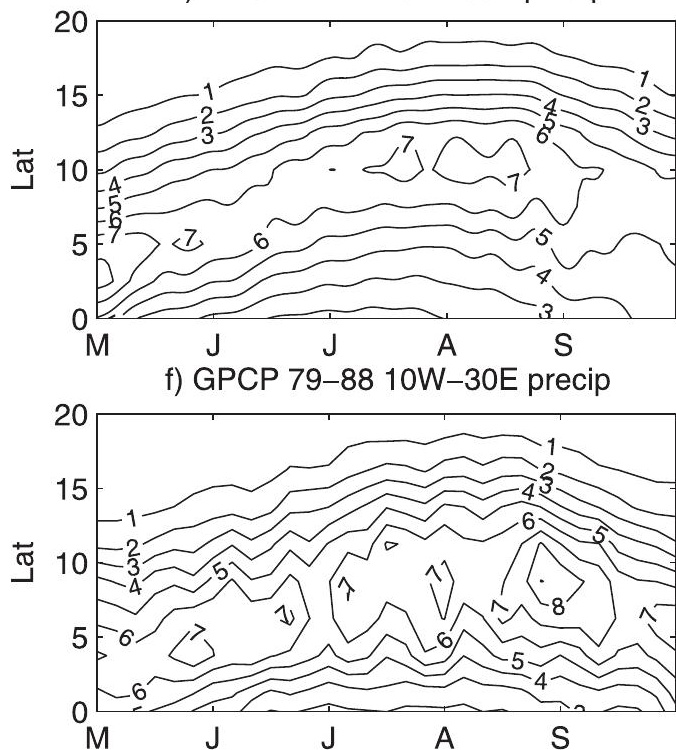
a) $10 \mathrm{~W}-10 \mathrm{E}$ precip warm-cold (loc.sig=0.11)

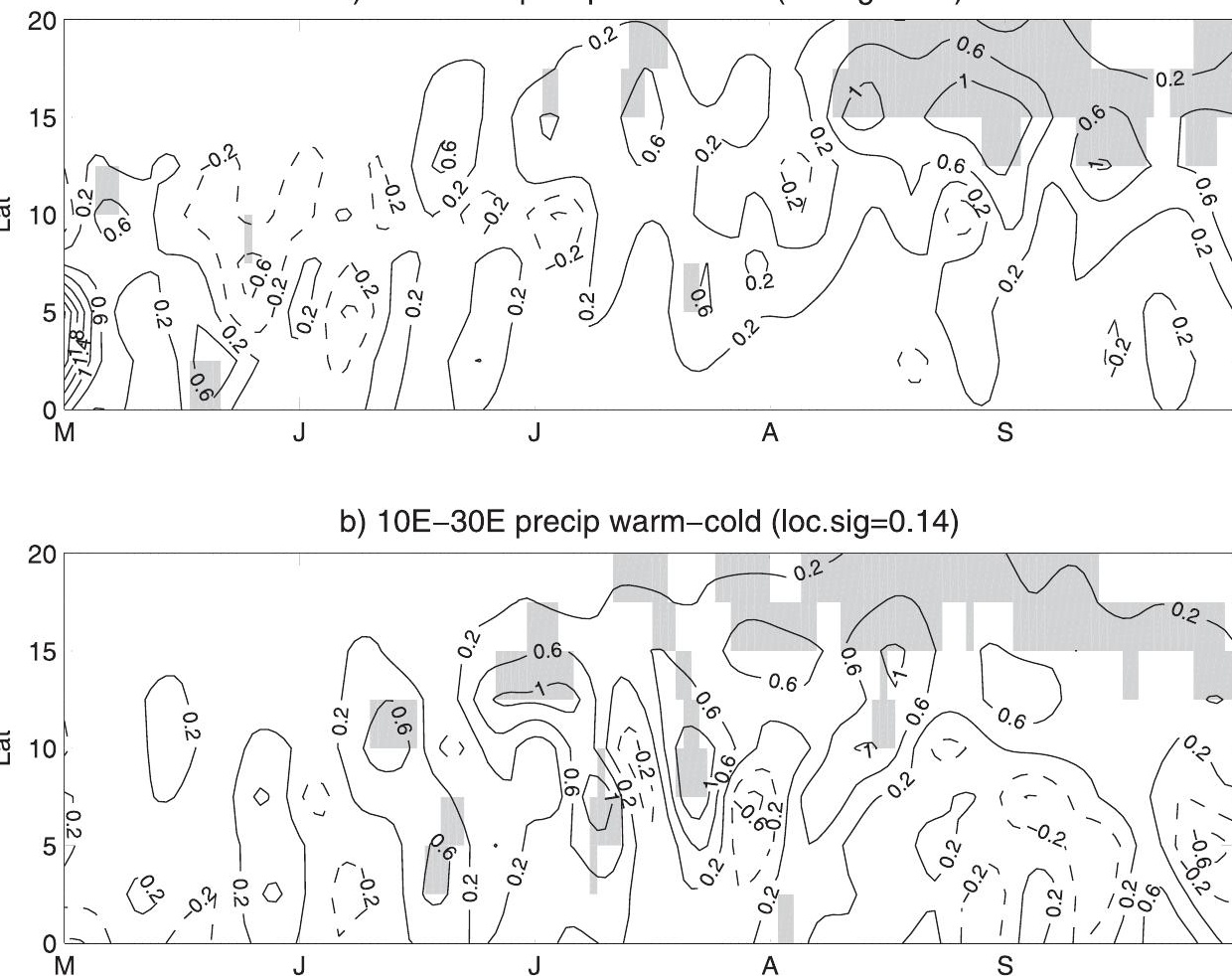


a) $10 W-10 E$ shum850 warm-cold (loc.sig=0.24)

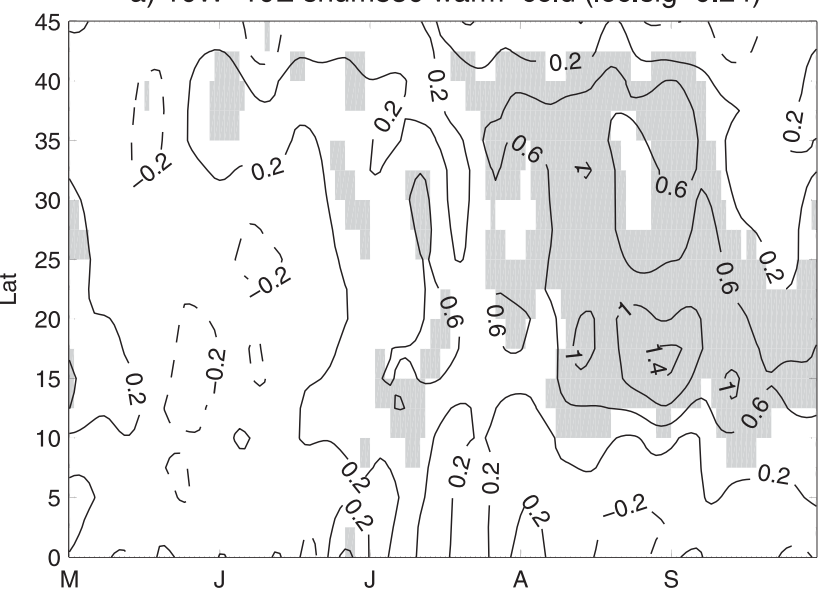

c) $10 \mathrm{~W}-10 \mathrm{E} \operatorname{div}(\mathrm{VIMT})$ warm-cold (loc.sig=0.03)

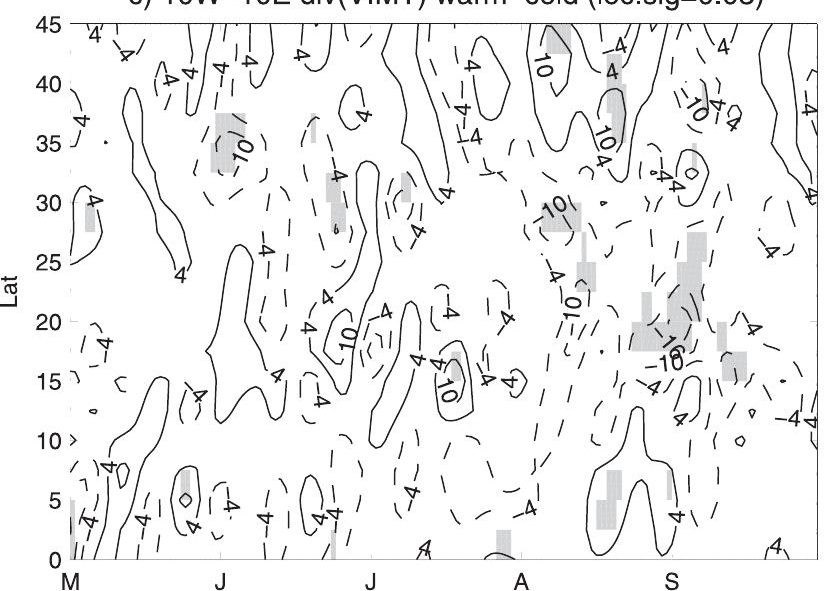

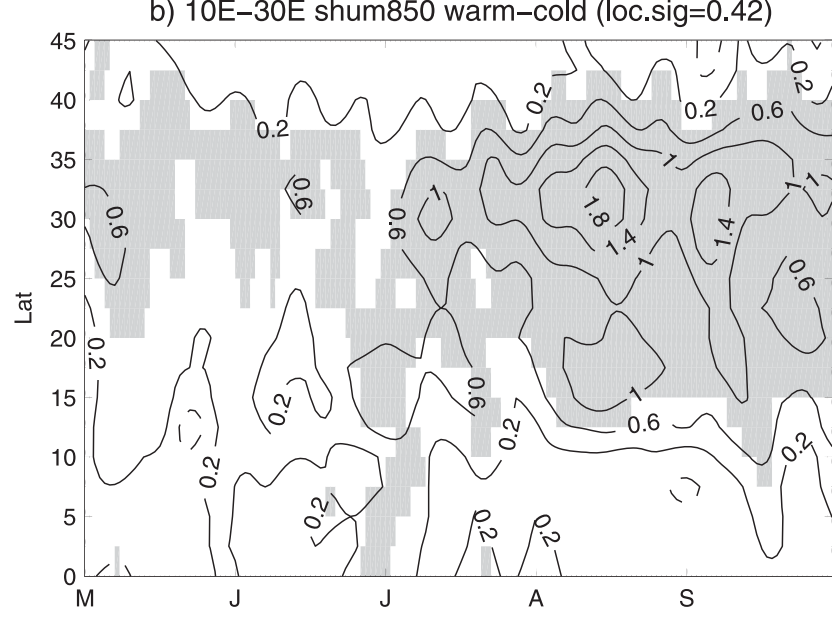

d) $10 \mathrm{E}-30 \mathrm{E} \operatorname{div}(\mathrm{VIMT})$ warm-cold (loc.sig=0.17)

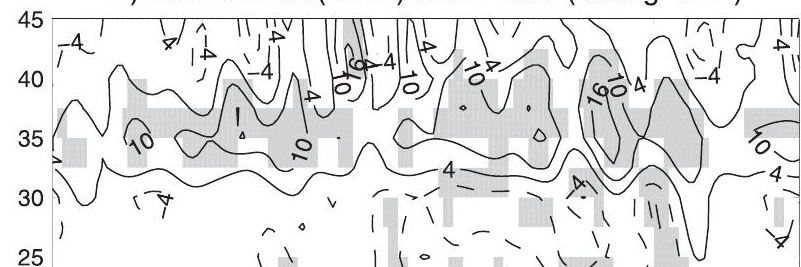

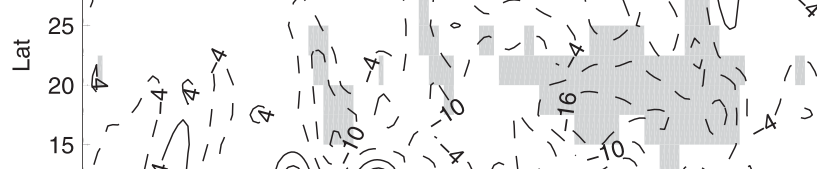

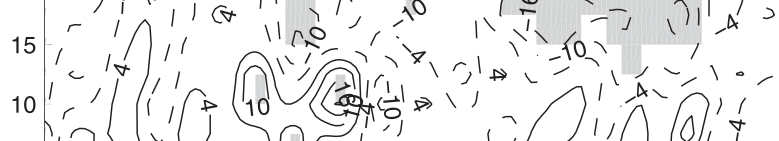

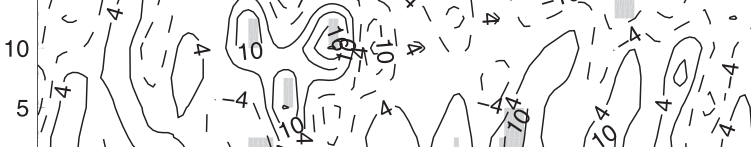

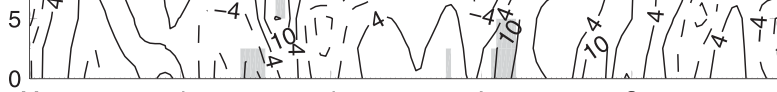



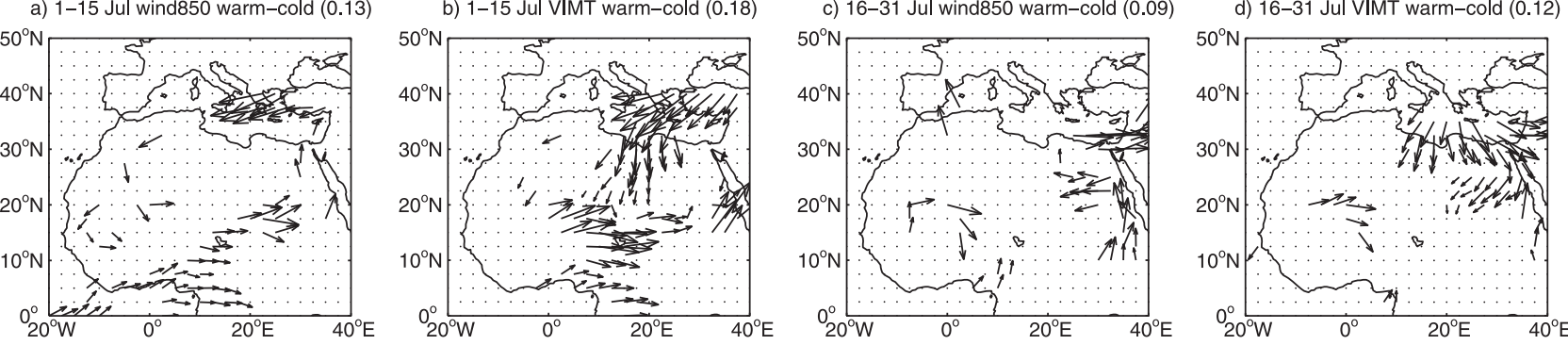

e) 1-15 Aug wind850 warm-cold (0.24)

f) 1-15 Aug VIMT warm-cold (0.31)

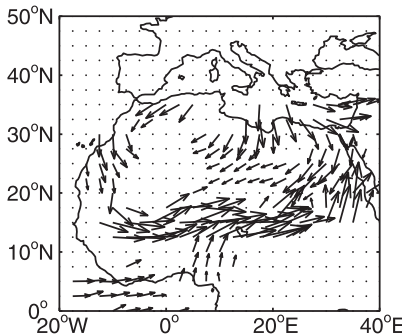

g) 16-31 Aug wind850 warm-cold (0.33)

h) 16-31 Aug VIMT warm-cold (0.28)
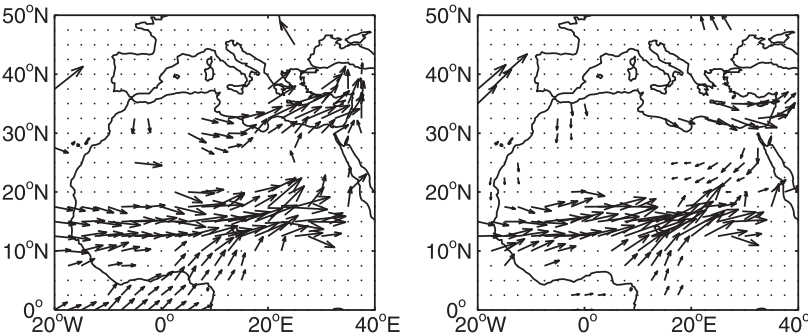

i) 1-15 Sep wind850 warm-cold $(0.30)$

j) 1-15 Sep VIMT warm-cold (0.37)
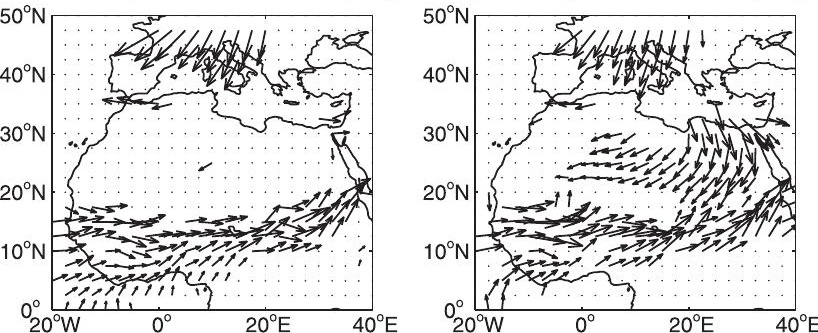

k) 16-30 Sep wind850 warm-cold (0.19)

I) 16-30 Sep VIMT warm-cold (0.15)
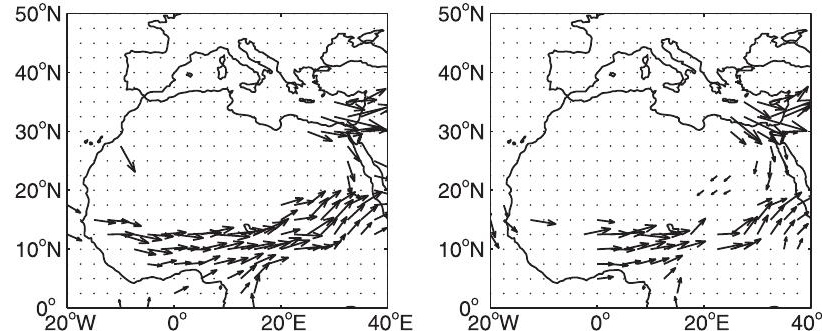
$10 \mathrm{~W}-30 \mathrm{E}$ uwnd600 warm-cold (loc.sig $=0.04$ )

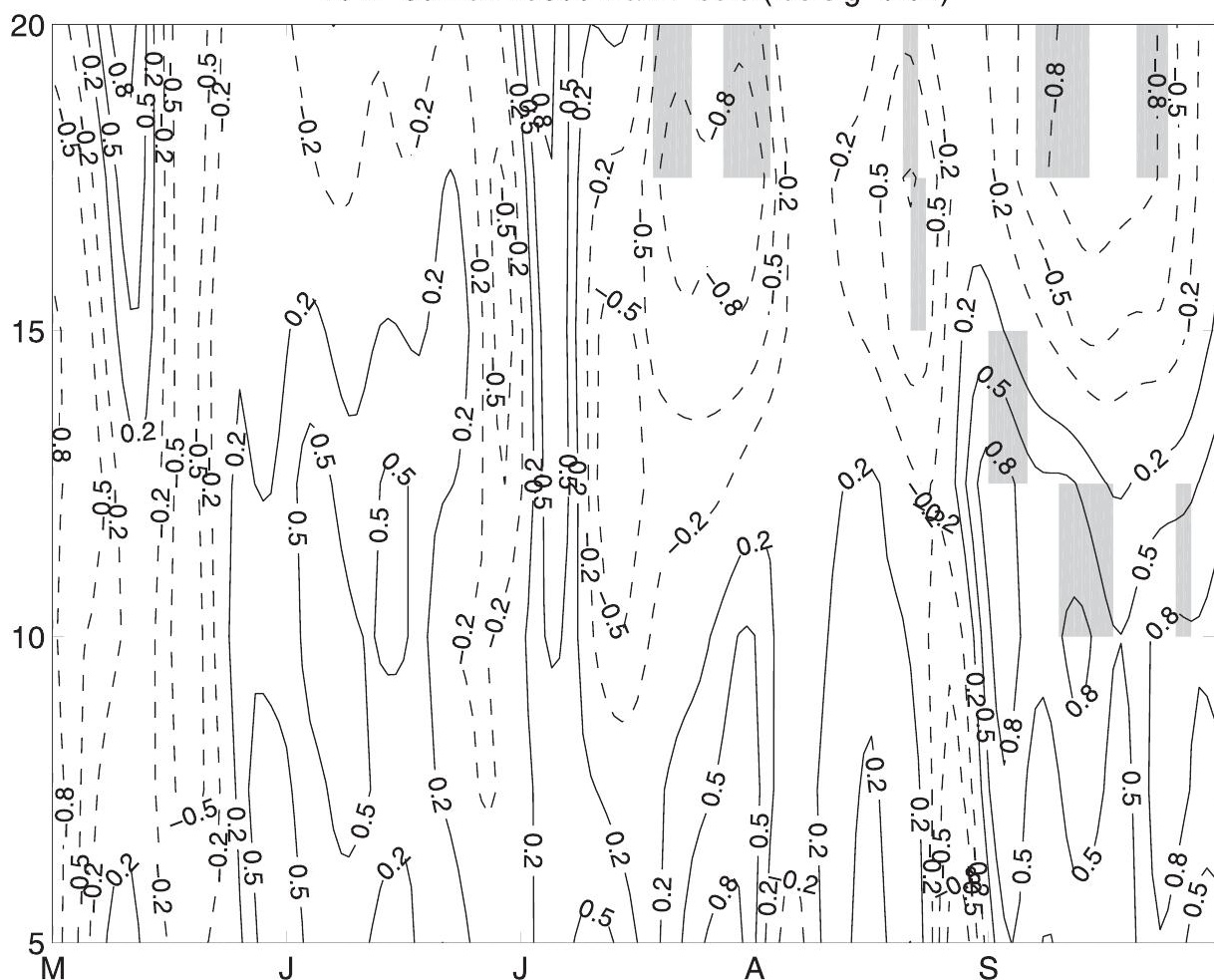


a) 1-15 Aug var(vwnd700 2-10day)
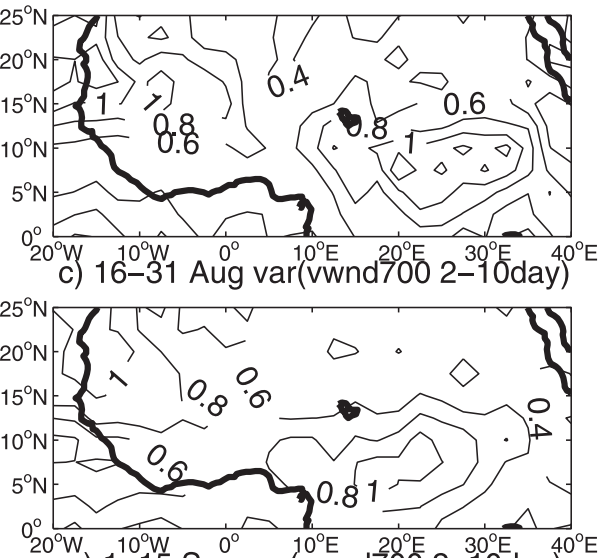

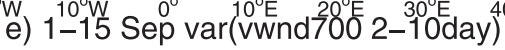

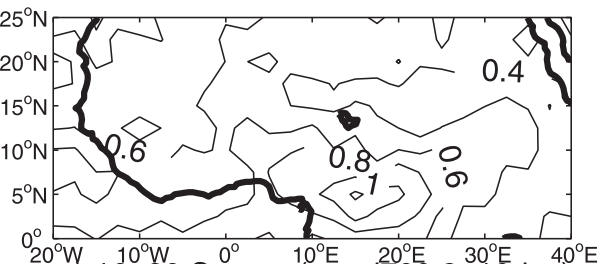

g) 16-30 Sep var(vwnd700 2-10day)

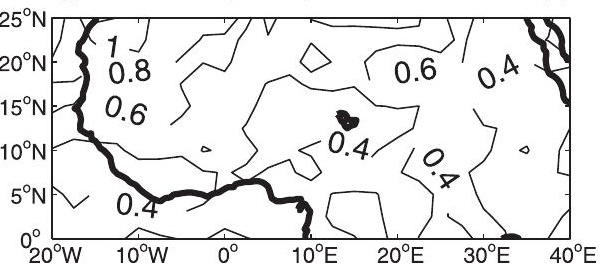

b) $1-15$ Aug warm-cold: pos=0.71 [0.33 0.66]
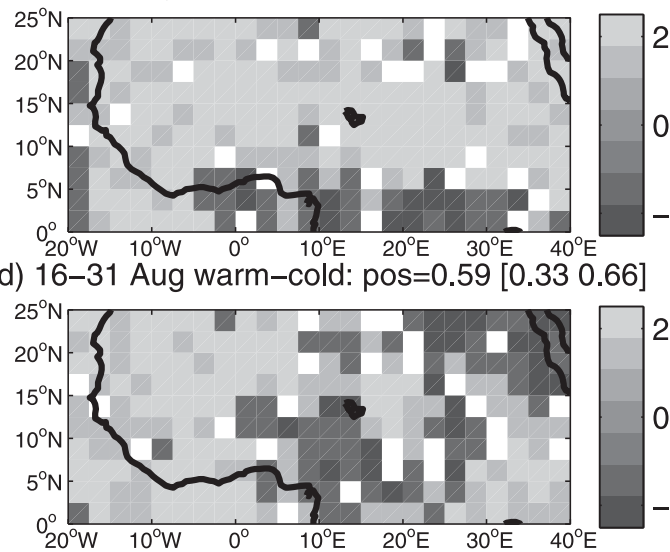

f) $1-15$ Sep warm-cold: pos $=0.53$ [0.33 0.66$]$

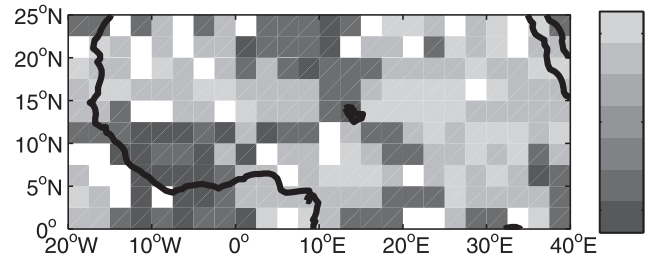

20

0

$-20$

h) 16-30 Sep warm-cold: pos $=0.41$ [0.33 0.66]

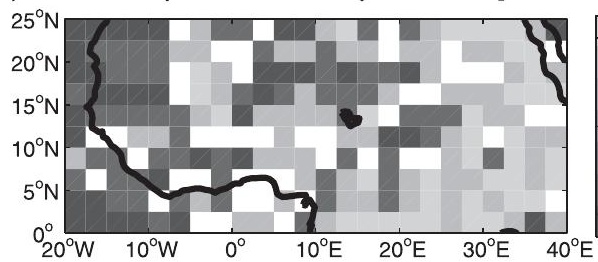

20

0

$-20$ 


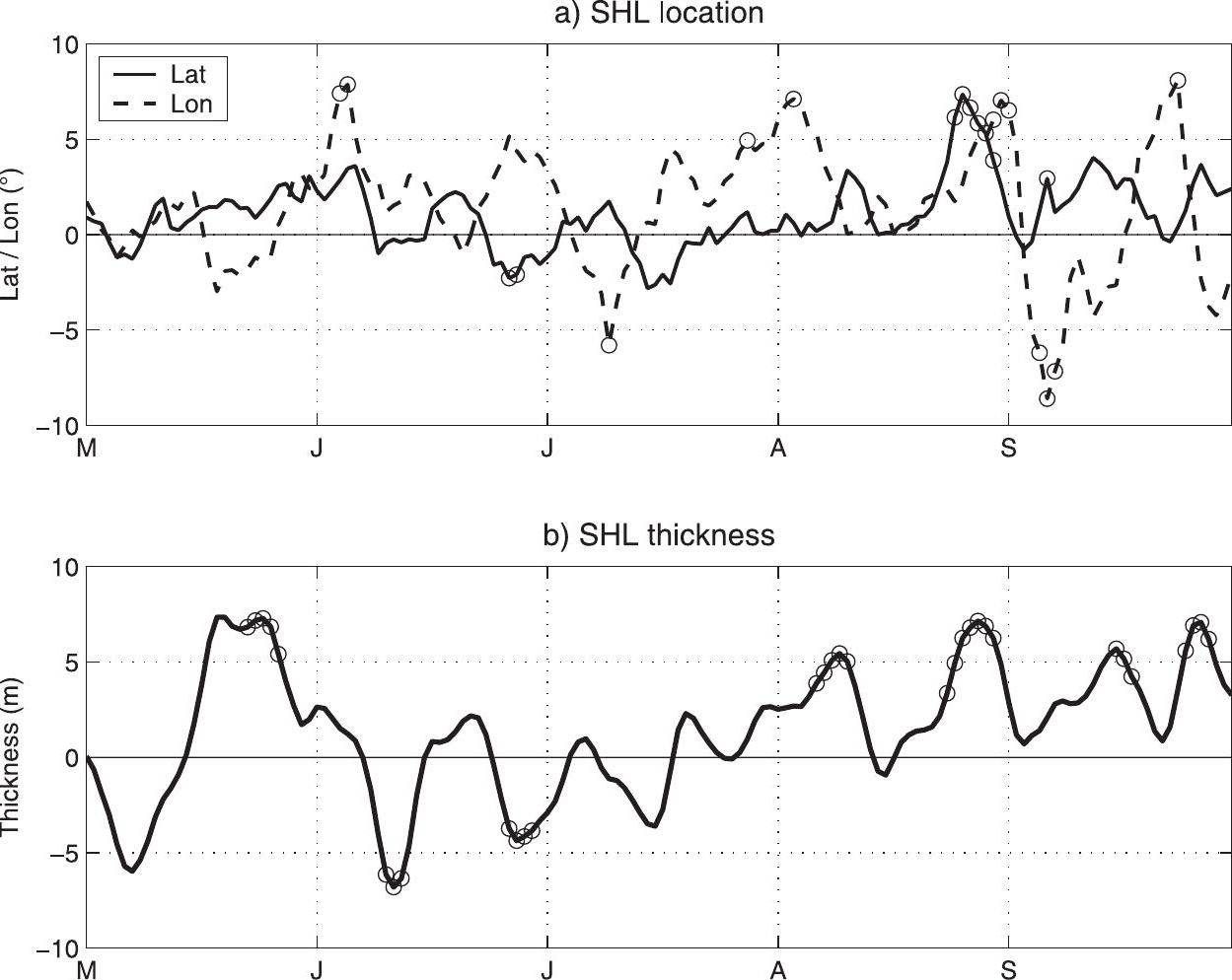


a) Sahel-Atlantic MSE1000 warm-cold

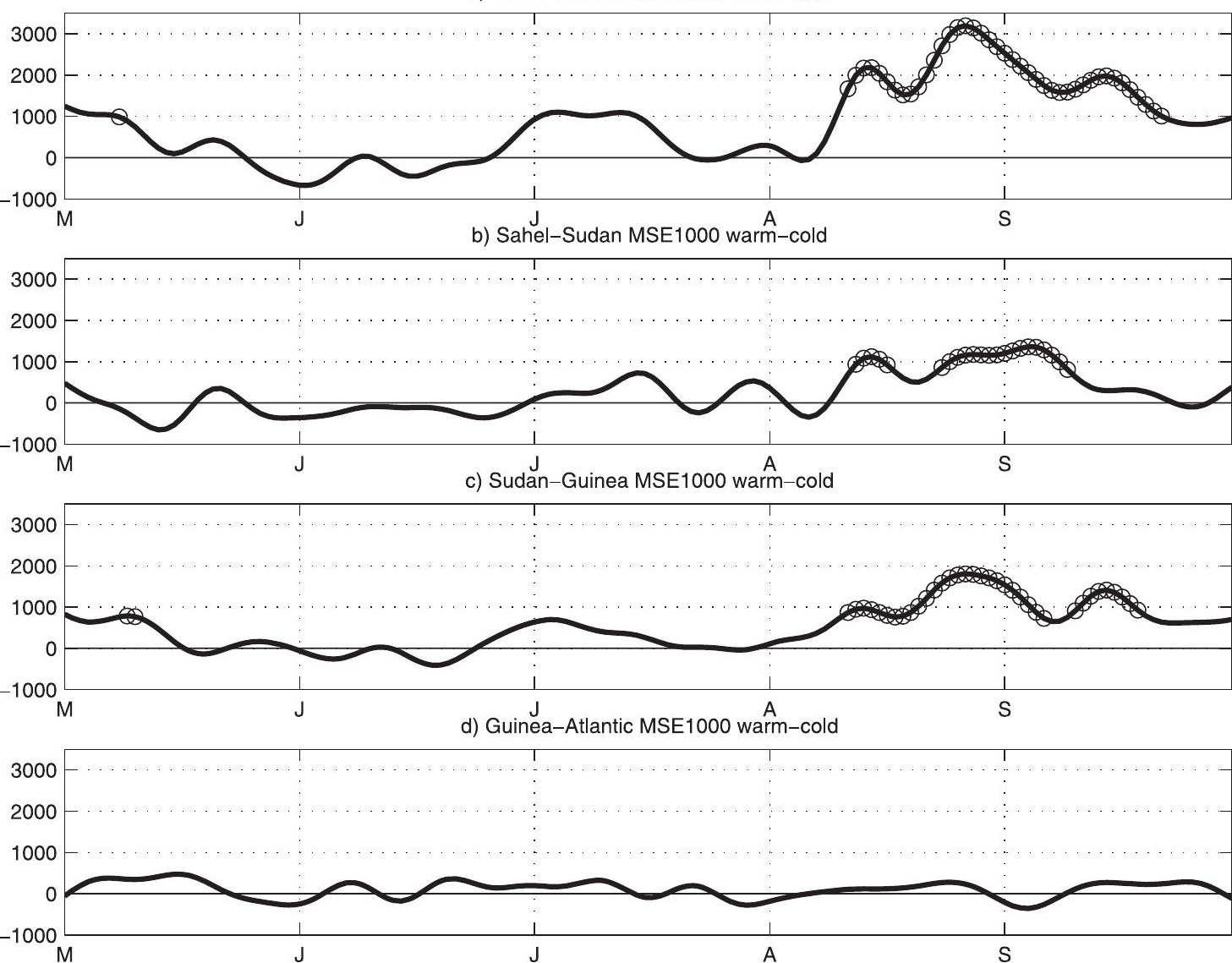

